\title{
Delivery of melittin-loaded niosomes for breast cancer treatment: an in vitro and in vivo evaluation of anti-cancer effect
}

\author{
Farnaz Dabbagh Moghaddam ${ }^{1 \dagger}$, Iman Akbarzadeh ${ }^{2 \dagger}$, Ehsan Marzbankia ${ }^{2}$, Mahsa Farid ${ }^{3}$, Leila khaledi ${ }^{4}$, \\ Amir Hossein Reihani ${ }^{5}$, Mehrnoosh Javidfar ${ }^{4}$ and Pejman Mortazavi ${ }^{6^{*}}$
}

\begin{abstract}
*Correspondence: sp.mortazavi@gmail.com ${ }^{\dagger}$ Farnaz Dabbagh Moghaddam and Iman Akbarzadeh contributed equally to this work

${ }^{6}$ Department of Pathology, Faculty of Specialized Veterinary Science, Science and Research Branch, Islamic Azad University, Tehran, Iran Full list of author information is available at the end of the article
\end{abstract}

\begin{abstract}
Background: Melittin, a peptide component of honey bee venom, is an appealing candidate for cancer therapy. In the current study, melittin, melittin-loaded niosome, and empty niosome had been optimized and the anticancer effect assessed in vitro on 4T1 and SKBR3 breast cell lines and in vivo on BALB/C inbred mice. "Thin-layer hydration method" was used for preparing the niosomes; different niosomal formulations of melittin were prepared and characterized in terms of morphology, size, polydispersity index, encapsulation efficiency, release kinetics, and stability. A niosome was formulated and loaded with melittin as a promising drug carrier system for chemotherapy of the breast cancer cells. Hemolysis, apoptosis, cell cytotoxicity, invasion and migration of selected concentrations of melittin, and melittin-loaded niosome were evaluated on 4T1 and SKBR3 cells using hemolytic activity assay, flow cytometry, MTT assay, soft agar colony assay, and wound healing assay. Real-time PCR was used to determine the gene expression. 40 BALB/c inbred mice were used; then, the histopathology, P53 immunohistochemical assay and estimate of renal and liver enzyme activity for all groups had been done.
\end{abstract}

Results: This study showed melittin-loaded niosome is an excellent substitute in breast cancer treatment due to enhanced targeting, encapsulation efficiency, PDI, and release rate and shows a high anticancer effect on cell lines. The melittin-loaded niosome affects the genes expression by studied cells were higher than other samples; down-regulates the expression of $B C 12, M M P 2$, and MMP9 genes while they up-regulate the expression of Bax, Caspase3 and Caspase9 genes. They have also enhanced the apoptosis rate and inhibited cell migration, invasion in both cell lines compared to the melittin samples. Results of histopathology showed reduce mitosis index, invasion and pleomorphism in melittin-loaded niosome. Renal and hepatic biomarker activity did not significantly differ in melittin-loaded niosome and melittin compared to healthy control. In immunohistochemistry, P53 expression did not show a significant change in all groups.

Conclusions: Our study successfully declares that melittin-loaded niosome had more anti-cancer effects than free melittin. This project has demonstrated that niosomes are suitable vesicle carriers for melittin, compare to the free form. 
Keywords: Breast cancer, Immunohistochemistry, Melittin, Nano-niosome, Renal and liver enzymes

\section{Background}

These days breast cancer increased in the female population (Jemal et al. 2011). Therapeutic options for the treatment of breast cancer are dependent on the specific biological characteristics of the tumor. If the tumor is low grade, node-negative and estrogen receptor-positive, hormone therapy may be recommended. However, if the tumor is high grade and node-positive, chemotherapy is generally practiced before targeted therapies depending on the hormonal/ErBb2 status of the tumor (Kontoyannis and Sweetland 2007). Anthracyclines, such as doxorubicin, epirubicin, and taxanes, are the current therapeutics for breast cancer treatment (Hernandez-Aya and Gonzalez-Angulo 2013). Nevertheless, fighting breast cancer still faces main obstacles, and finding new agents with the potential to be used in combination with current medicines to improve the therapeutic outcome and reduce the side effects is highly appreciated.

The two main components of honey bee venom are phospholipase A2 and melittin. Melittin has a pro-apoptotic effect and shows anti-tumor activity (Oršolić 2012). Melittin $(\mathrm{C} 131 \mathrm{H} 229 \mathrm{~N} 39 \mathrm{O} 31)$ is an amphiphilic peptide with 26 amino acid residues (Eisenberg 1984) and has membrane-perturbing effects, like pore formation, fusion, and vesiculation (Ladokhin et al. 1997; Dempsey 1990). Melittin has been used in tumorbearing mice research because of its cytotoxicity on different tumor cell lines and its capacity to inhibit cell growth or induce necrosis and apoptosis (Jo et al. 2012; Soman et al. 2009). Melittin can induce apoptosis, cell cycle arrest, growth inhibition in different cancer cells (Jo et al. 2012; Park et al. 2010, 2011; Liu et al. 2008) and immunoregulatory activity (Zhu et al. 2000). Honey bee venom can enhance $\mathrm{T}$ lymphocyte esterase expression in sarcoma mice and increase T lymphocyte functions (Kubo et al. 1999). Melittin augments Th1 cells function and is used to therapy of low immune function, cancer and viral infection (Qiubo 2000). Melittin has shown significant efficacy in inducing apoptosis, necrosis, mitochondrial disruption, blocking of angiogenesis, cell cycle arrest and inhibition of cancer cell metastasis and invasion (Rady et al. 2017) (Fig. 1).

The $4 \mathrm{~T} 1$ is a transplantable breast tumor cell line that has highly tumorigenic, invasive and, unlike most tumor models, so can spontaneously metastasize from the primary tumor in the mammary gland to multiple distant areas such as lymph nodes, liver, blood, brain, lung, and bone (Pulaski and Ostrand-Rosenberg 2000). 4T1 tumor cells are easily transplanted into the mammary gland so that the primary tumor grows in the correct area (Moghaddam et al. 2016). As breast cancer in humans, 4T1 metastatic disease develops spontaneously from the primary tumor; also, the progressive spread of 4T1 metastases to the draining lymph nodes and other vital organs is similar to that of human breast cancer (Pulaski and Ostrand-Rosenberg 2000).

The $B c l 2$ protein family, of which $B a x$ is a member, plays a critical role in cell death or survival (Basu and Haldar 1998; Bouchalova et al. 2014). Bcl2 is expressed in solid tumors, such as breast, colorectal, prostate, stomach, lung, ovarian, and cancers (Bouchalova et al. 2014). Bcl2 family proteins are expressed in normal mammary tissue (Bouchalova et al. 2014). Bcl2-positive expression in breast cancer a sign of estrogen receptor functional activity (Aleskandarany et al. 2015; Choi et al. 2014). The 


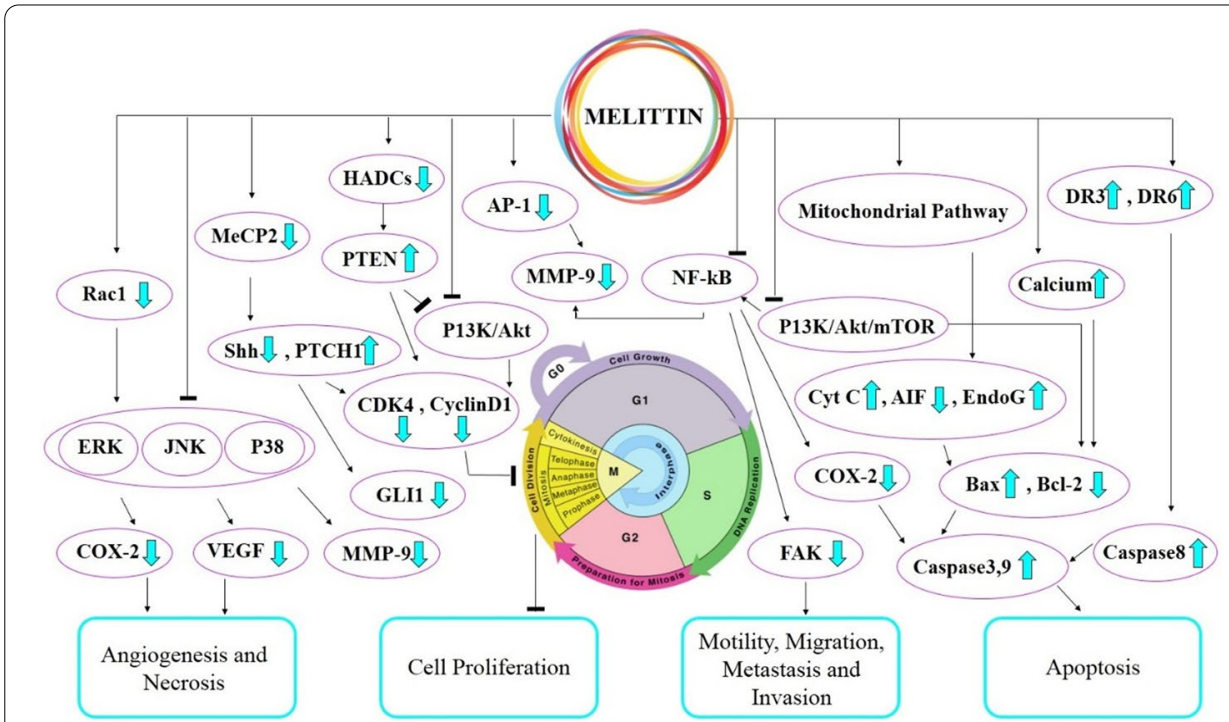

Fig. 1 Schematic of melittin functional pathways in the cancer cell. Melittin has shown significant efficacy in inducing apoptosis, necrosis, mitochondrial disruption, blocking of angiogenesis, cell cycle arrest and inhibition of cancer cell metastasis and invasion

balance between $B a x$ as a pro-apoptotic and $B c l 2$ as an anti-apoptotic protein level is necessary for the regulation of apoptosis and overexpression of Bax leads to apoptosis in cells, suggesting that tight regulation of $B a x$, from transcription to post a translation, is essential for cell survival (Callagy et al. 2006).

$M M P 2$ and $M M P 9$ are mainly secreted by tumor cells and stromal cells in the form of zymogens, and they play the main role in degrading extracellular matrices and metastasis and promoting tumor invasion (Zhang et al. 2014; Iochmann et al. 2009). Melittin has anti-cancer effects on 4T1 breast cancer cells with up-regulation on Bax, Mfn1, Caspase 3 and Caspase 9 and down-regulation on Bcl2, Drp1, MMP2 and $M M P 9$ geans, so it can be the best candidate for further research on breast cancer treatment (Moghaddam et al. 2020). Therefore, combination therapy with a more precise technique to maximize the efficacy of the therapy is valuable. Nanoparticles conjugation with chemotherapeutic drugs and natural compounds with anti-cancer effect showed some promising outcomes, with many of them approved for the treatment of different cancer types (Laprise-Pelletier et al. 2018).

Nanotechnology is an innovative scientific field that takes account of the eccentric features at the nanoscale. Nanoparticles provide a high surface area to mass ratio and usually interact efficiently with their surroundings, but they can work as contained carriers for their constituent molecules rather than the same molecules in solution (Deljoo et al. 2019; Shad et al. 2020; Shirzad et al. 2019). Therefore, nanoparticles are promising carriers for the targeted delivery; of therapeutic substitutes. Nanoparticles have been designed for optimizing size and characteristics to magnify the biodistribution of cancer drugs in the bloodstream. They can transfer their loaded active drug to cancer cells by selectively using tumors' specific stimuli (Hedayati et al. 2020; Akbarzadeh et al. 2021). Drug resistance is another obstacle that hinders the efficacy 
of molecularly targeted and precise chemotherapeutic operators and can reduce nanoparticle applications. Multifunctional and multiplex nanoparticles are now being actively investigated as aiding, personalized, and tailored cancer medication. Drug delivery systems are characterized as formulations aiming to convey a drug to the desired area of action through the body (Akbarzadeh et al. 2021; Akbarzadeh 2020). Niosomes are special drug carriers developed by the self-association of cholesterol and non-ionic surfactants in an aqueous phase (Ghafelehbashi et al. 2019). They are an alternative to phospholipid vesicles to encapsulate hydrophobic and hydrophilic drugs providing sufficient encapsulation capability, biocompatibility, biodegradation, low preparation cost, and ample stability (Hedayati et al. 2020; Akbarzadeh et al. 2021).

In the present in vitro and in vivo study, we aimed to study the delivery of melittin using niosomal formulations to increase its stability and controlled release to improve anticancer properties, induce apoptosis, inhibit migration and invasion, and effects on Bax, Bcl2, Caspase3, Caspase9, MMP2, and MMP9 mRNA expression in 4T1 and SKBR3 breast cancer cells and BALB/c tumor mice.

\section{Result}

\section{Melittin-loaded niosomes characteristics}

The encapsulation efficiency (EE) and the size of the niosome much depend on the type of surfactants and the volume of cholesterol (i.e., lipid) in the niosomal structure because any change in the chemical species and chemical formation undeviatingly affects the hydrophilic-lipophilic balance (HLB) in the niosomal formulation. A suitable drug delivery system must have high encapsulation efficiency, a small size, and a structure to carry an ample amount of drug, penetrate the target tissue, and release the drug molecules inside the target tissue. However, there is an obscure association between the size and encapsulation efficiency in the niosomal formulations. Various formulations have been prepared and investigated to optimize the arrangement. Table 1 shows the size, polydispersity index (PDI), and EE of the niosomal formulation in terms of the Span 60 percentage (i.e., in the Span 60/Tween 60 mixture) and cholesterol content for a specific amount $(1 \mathrm{mg})$ of melittin as a drug molecule, then sonicated for five minutes to provide more uniform niosomes. Melittin has multiple hydrophilic groups (e.g., $\mathrm{OH}$, and $\mathrm{NH}$ ), which inaugurates an interaction

Table 1 Effect of the surfactant:cholesterol and Span 60:Tween 60 with various molar ratios on entrapment efficiency (EE \%), size and PDI in melittin-loaded niosome

\begin{tabular}{llllllll}
\hline Formulations & $\begin{array}{l}\text { Surfactant: } \\
\text { cholesterol } \\
\text { (molar ratio) }\end{array}$ & $\begin{array}{l}\text { Span } \\
\mathbf{6 0 : T w e e n} \\
\mathbf{6 0}(\mathbf{m o l a r} \\
\text { ratio) }\end{array}$ & $\begin{array}{l}\text { Drug } \\
\text { concentration } \\
\text { (mg/ml) }\end{array}$ & $\begin{array}{l}\text { Sonication } \\
\text { time }(\mathbf{m i n})\end{array}$ & $\begin{array}{l}\text { Vesicle } \\
\text { size }(\mathbf{n m}, \\
\text { average } \pm \text { SD) }\end{array}$ & $\begin{array}{l}\text { Polydispersity } \\
\text { index (average } \\
\pm \text { SD) }\end{array}$ & $\begin{array}{l}\text { EE (\%) } \\
\text { (average } \pm \text { SD) }\end{array}$ \\
\hline$T_{1}$ & $1: 1$ & $100: 0$ & 1 & 5 & $197.4 \pm 8.3$ & $0.175 \pm 0.024$ & $60.25 \pm 1.75$ \\
$T_{2}$ & $1: 1$ & $50: 50$ & 1 & 5 & $121.4 \pm 8.7$ & $0.211 \pm 0.012$ & $79.32 \pm 1.34$ \\
$T_{3}$ & $1: 1$ & $0: 100$ & 1 & 5 & $158.4 \pm 6.5$ & $0.192 \pm 0.021$ & $67.21 \pm 0.92$ \\
$T_{4}$ & $2: 1$ & $100: 0$ & 1 & 5 & $235.7 \pm 10.1$ & $0.254 \pm 0.016$ & $51.33 \pm 2.78$ \\
$T_{5}$ & $2: 1$ & $50: 50$ & 1 & 5 & $165.3 \pm 9.2$ & $0.184 \pm 0.008$ & $75.45 \pm 2.34$ \\
$T_{6}$ & $2: 1$ & $0: 100$ & 1 & 5 & $208.9 \pm 5.6$ & $0.224 \pm 0.017$ & $64.75 \pm 1.52$ \\
\hline
\end{tabular}


between melittin and the hydrophilic chain of niosome. Hence, a unification of two surfactants with low and high HLB may result in melittin's tremendous encapsulation with the small size of niosomal formulation. Tween 60 is a non-ionic surfactant with a high hydrophilic moiety, while Span 60 is a non-ionic surfactant with a hydrophobic fraction.

Consequently, varying Span 60/Tween 60 ratios could accurately regulate the HLB of the surfactants and directly modify their cooperation with drug molecules (Hedayati et al. 2020). It can be concluded from Table 1, adding Tween 60 to the formulation represents the zenith encapsulation efficacy and PDI, while it provides the smallest size (Table 1, T2, and T5). As shown in Table 1, T1 to T3, when the surfactant/cholesterol ratio was $1: 1$, the particles' mean size is smaller than when the ratio changed to $2: 1$, due to a thicker lipid layer, which cholesterol provided. However, applying Tween 60 to the formulation provided an adequate EE and size; utilizing it separately in cholesterol combination without Span 60 resulted in a larger size and less EE (Table 1, T3, and T6). It was evident from the experiment results that Span 60 cannot provide either a suitable encapsulation efficacy and particle size (Table 2, T1, and T5). All the results conclude that the combination of Span 60 and Tween 60 with the cholesterol possesses the optimum drug carrier for hydrophilic drugs like melittin (Alemi et al. 2018; Nasseri 2005).

\section{Morphological characterization}

The morphology of melittin-loaded niosomes was assessed using SEM and TEM methods. In this study, the niosomes particle size was less than $50 \mathrm{~nm}$, much smaller than dynamic light scattering (DLS) observation. This variance can be due to the difference between SEM and DLS techniques (Hedayati et al. 2020); in SEM, the dried samples are examined, but in DLS, the samples might be hydrated; thus, the particles' size in the DLS test is more prominent. The examination demonstrates a smooth surface, spherical form, and separated firm boundaries with a uniform distribution. The size of nanoparticles has been assessed using DLS. As Fig. 2 shows, the average diameter is $121.4 \mathrm{~nm}$, which represents the optimum formulation size. As had been mentioned before, other formulations did not provide acceptable sizes for drug delivery applications.

Table 2 The kinetic release models and the parameters obtained for optimum niosomal formulation

\begin{tabular}{|c|c|c|c|c|}
\hline Release model & Melittin solution & $\begin{array}{l}\text { Melittin-loaded } \\
\text { niosome (pH 7.4) }\end{array}$ & $\begin{array}{l}\text { Melittin-loaded } \\
\text { niosome } \\
\text { (pH 6.5) }\end{array}$ & $\begin{array}{l}\text { Melittin- } \\
\text { loaded } \\
\text { niosome } \\
\text { (pH 5.4) }\end{array}$ \\
\hline $\begin{array}{l}\text { Zero-order } \\
Q_{t}=Q_{0}+K_{0} t\end{array}$ & $R^{2}=0.5679$ & $R^{2}=0.7368$ & $R^{2}=0.7698$ & $R^{2}=0.7784$ \\
\hline $\begin{array}{l}\text { First-order } \\
\text { Log } Q_{t}=\log Q_{0}+K_{1} t\end{array}$ & $R^{2}=0.9643$ & $R^{2}=0.8319$ & $R^{2}=0.8833$ & $R^{2}=0.9380$ \\
\hline $\begin{array}{l}\text { Higuchi } \\
Q_{t}=Q_{0}+K H t_{0.5}\end{array}$ & $R^{2}=0.7415$ & $R^{2}=0.8845$ & $R^{2}=0.9073$ & $R^{2}=0.9140$ \\
\hline $\begin{array}{l}\text { Korsmeyer-Peppas } \\
\frac{M_{t}}{M}=k t^{n}\end{array}$ & $\begin{array}{l}R^{2}=0.8337 \\
n=0.4435\end{array}$ & $\begin{array}{l}R^{2}=0.9003 \\
n=0.4454\end{array}$ & $\begin{array}{l}R^{2}=0.9297 \\
n=0.4141\end{array}$ & $\begin{array}{l}R^{2}=0.9431 \\
n=0.4021\end{array}$ \\
\hline
\end{tabular}



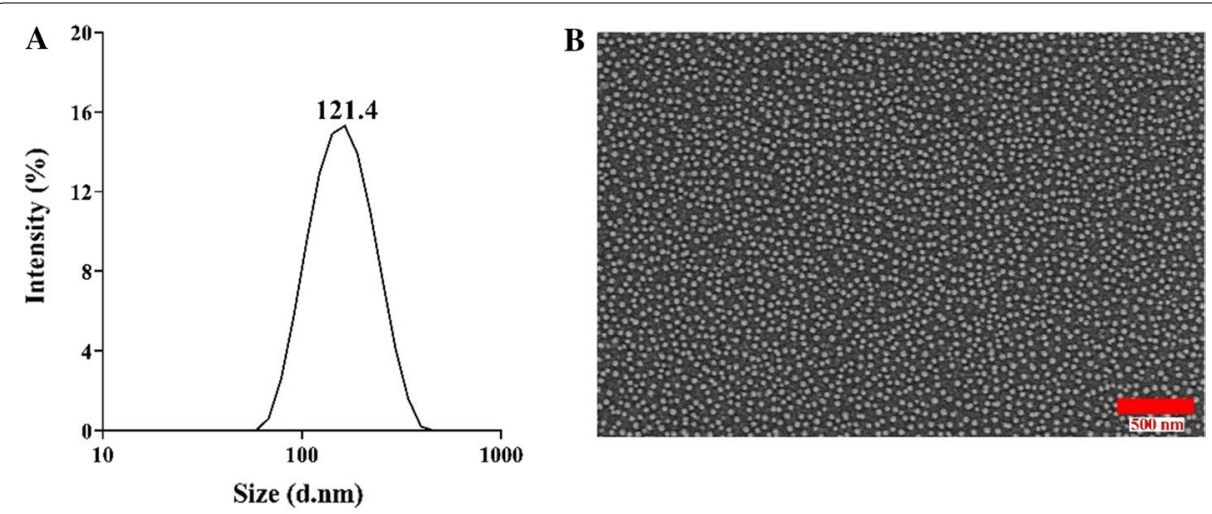

C

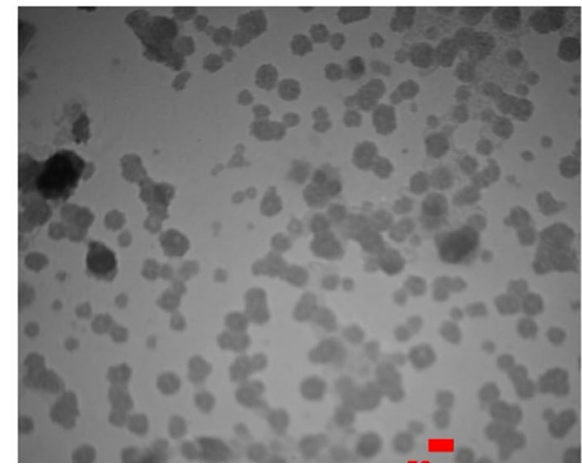

Fig. 2 Morphological determination of optimized formulation. A Analysis of particle size distribution of melittin-loaded niosome by dynamic light scattering (DLS); B scanning electron microscopy (SEM); C transmission electron microscopy (TEM)

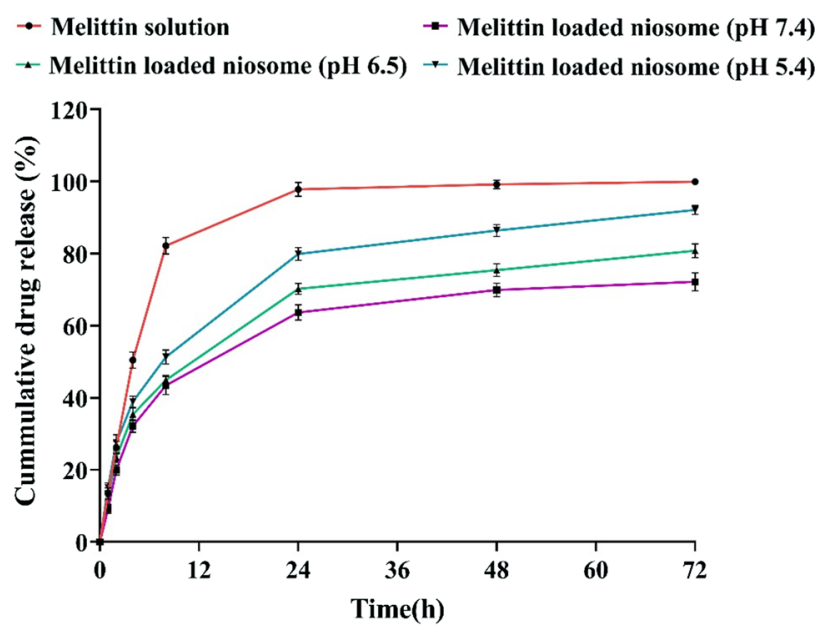

Fig. 3 A comparison between in vitro drug release profile of melittin and melittin-loaded niosome from the dialysis bag in different $\mathrm{pH}(7.4,6.5$ and 5.4$)$ at $37^{\circ} \mathrm{C}$

\section{In vitro drug kinetic and release studies of melittin from niosomes}

To investigate the in vitro drug release, every selected formulation drug release profile was examined for $72 \mathrm{~h}$ in 7.4, 6.5, and $5.4 \mathrm{pH}$ at the body temperature. As it can be 
seen in the "Release" diagram (Fig. 3), the free drug first had burst in the bloodstream (82.19\% during the first $8 \mathrm{~h}$ ); after $24 \mathrm{~h}$, it had reached to monotonous release manner for the next hours. Niosomal melittin release profile surveillances showed that in $7.4 \mathrm{pH}$, $43.45 \%$ of the drug had penetrated in the first eight hours; this rate increased to 44.91 in $6.5 \mathrm{pH}$ and $51.29 \%$ in $5.4 \mathrm{pH}$. After $72 \mathrm{~h}, 72.19 \%, 80.81 \%$, and $92.11 \%$ of the drug released into the bloodstream in $5.4 \mathrm{pH}, 6.5 \mathrm{pH}$, and $7.4 \mathrm{pH}$, respectively, attributed to the acidic condition niosomes-swelling structure (Rinaldi et al. 2017). Niosomes' acidic departure is related to electrophilic addition reactions. The drug-loaded niosomes had studied for the release rate. Acidic $\mathrm{pH}$ crushed the niosomes structure, increasing the release rate, increasing the toxicity as the tumor wards habitually have the acidic condition (Naderinezhad et al. 2017). Also, the acidic condition affects the melittin and increases the osmotic pressure, which induces more cytotoxicity (Benachir and Lafleur 1996; Bello et al. 1982). Melittin's release data had been mathematically measured, in zero-order, first-order, Korsmeyer-Peppas, and Higuchi's orders, in three $\mathrm{pH}$ ranges $(7.4,6.5$, and 5.4) for $72 \mathrm{~h}$ in body temperature (Table 2). Free drug release followed the first-order model, with the rate of $R^{2}=0.9643$, representing a drug-concentration release (this applies for melittin, as a separate free drug). Melittin-loaded niosomes had followed the Korsmeyer-Peppas model $(n)$ in either 7.4, 6.5, and 5.4 pH. This fact declared that the release mechanism is the diffusion-erosion arrangement. The release rate in each, $5.4,6.5$, and 7.4 $\mathrm{pH}$, are $R^{2}=0.9431$ with $n=0.4021, R^{2}=0.9297$ with $n=0.4141$, and $R^{2}=0.9003$ with $n=0.4454$, respectively (Fu and Kao 2010).

\section{Physical stability study of niosomal melittin}

Vesicle size, PDI, and EE were analyzed by putting them at $4{ }^{\circ} \mathrm{C}$ and $25^{\circ} \mathrm{C}$, and on days $0,14,30$, and 60 after the preparation to pick the optimal melittin niosomal formulations and physical stability. Interestingly, the observations demonstrated that the temperature affected neither the size of particles, PDI, or EE percentage and possesses the minimum size with the mean of $121.4 \mathrm{~nm}$, maximum PDI $(0.211)$, and EE (79.32\%) on the day the formulation just prepared. As shown in the stability figure (Fig. 4), in the following days to day 60 , the temperature affected all the parameters. Increasing the temperature caused size expansion, more PDI, and EE reduction. The EE reduction is due to the rise of drug release in temperature increase (Nasseri 2005). As the temperature can affect the rigidity and elasticity, growing the pores of the niosomes; could be effective on the particles size and PDI and increase either of them and reduce the EE to its minimum amount $(55.19 \%)$. As can be concluded from the stability results, the stability is better at $4{ }^{\circ} \mathrm{C}$ attributed to the rigidity and elasticity of the niosomes, because at $25^{\circ} \mathrm{C}$, the grown pores caused bigger size, more PDI, and less EE.

\section{Hemolytic activity of melittin in BALB/c mice erythrocytes}

A powerful hemolytic activity was observed in the purified melittin from honey bee venom. The results showed increased melittin hemolytic activity in $1,2,4$, and $8 \mu \mathrm{g} /$ $\mathrm{ml}$ compare to positive control (Triton X-100) $\left(P<0.001^{* * * *}\right)$. The melittin HD50 value obtained in $2 \mu \mathrm{g} / \mathrm{ml}$ shows hemolysis of $50 \%$ of erythrocytes. The hemolysis effect of empty niosome and melittin-loaded niosome on mice erythrocytes was also investigated. The empty niosome hemolytic activity was $(9.22 \%)$ and the melittin-loaded niosome in 

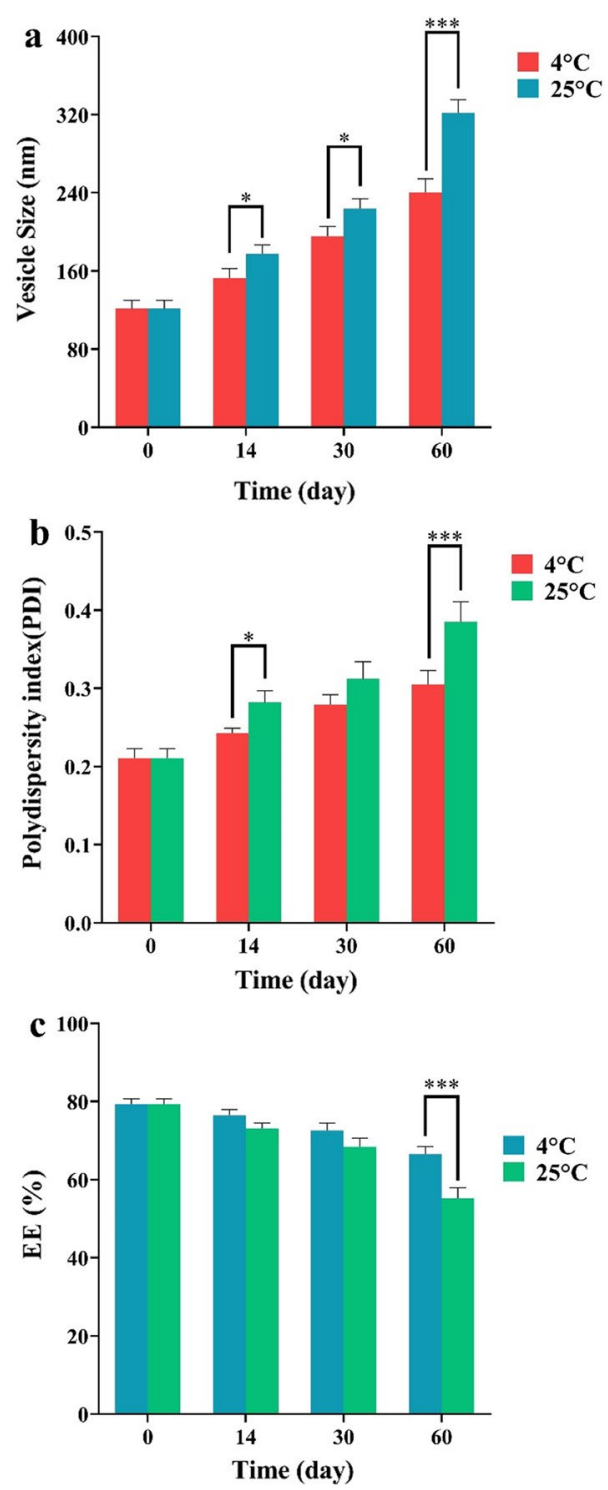

Fig. 4 Comparing stability of optimum formulation at $4{ }^{\circ} \mathrm{C}$ and $25^{\circ} \mathrm{C}$. Mean particle size (a), PDI (b) and EE \% (c) were studied as stability parameters. Results are represented by mean $\pm \operatorname{SD}(n=3) .{ }^{*} P<0.05,{ }^{* * *} P<0.001$

$4 \mu \mathrm{g} / \mathrm{ml}$ and $8 \mu \mathrm{g} / \mathrm{ml}$ were 13.53 and $19.82 \%$. These values were low compared to the percentage of hemolysis of melittin in different concentrations, but showed a statistically significant increase compared to the positive control (Triton X-100) $\left(P<0.001^{* * * * *}\right)$ (Fig. 5).

\section{Cell proliferation assay}

The treatment of two breast cancer cells (4T1 and SKBR3 cells) with niosomal formulation resulted in a higher inhibitory effect (less cell viability) compared to free drug solutions. To determine the inhibitory effect of individual melittin as a free form and melittin-loaded niosome as a niosomal form on $4 \mathrm{~T} 1$ and SKBR3 cells. A dose-response 


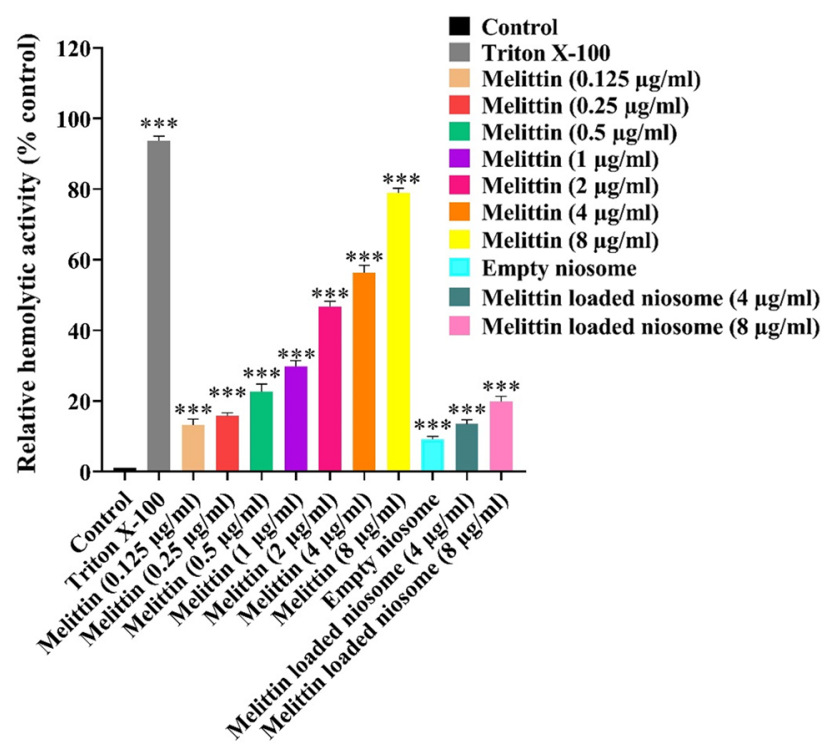

Fig. 5 Melittin, melittin-loaded niosome, and empty niosome hemolytic activity compared with the positive control (Triton X-100). All experiments were performed in triplicate. Data are shown as mean \pm SEM. The mean values with different superscript letters are significantly different $(P \leq 0.05)$

experiment had been performed for both groups. As indicated in individual treatments with the free form and the niosomal form resulted in growth inhibition of 4T1 and SKBR3 cells in a dose-dependent pattern. The IC50 value was evaluated in all study groups on $4 \mathrm{~T} 1$ mice breast cancer cell line after 48- and 72-h treatment. In study groups melittin and melittin-loaded niosome IC50 values, respectively, were $143.20 \mu \mathrm{g} / \mathrm{ml}$ and $75.58 \mu \mathrm{g} / \mathrm{ml}$ after $48 \mathrm{~h}$, and $40.62 \mu \mathrm{g} / \mathrm{ml}, 27.17 \mu \mathrm{g} / \mathrm{ml}$ after $72 \mathrm{~h}$. According to the results in all groups, IC50 remarkably decreased after $72 \mathrm{~h}$ compared to $48 \mathrm{~h}(P<0.001$ $*$ *) (Fig. 6a). In SKBR3 human breast cancer cell line after 48- and 72-h treatment IC50 value was evaluated. In melittin, and melittin-loaded niosome groups, IC50 values, respectively, were $87.87 \mu \mathrm{g} / \mathrm{ml}$, and $47.65 \mu \mathrm{g} / \mathrm{ml}$ after $48 \mathrm{~h}$, and $50.56 \mu \mathrm{g} / \mathrm{ml}, 31.05 \mu \mathrm{g} /$ $\mathrm{ml}$ after 72 -h treatment. According to the results in study groups, IC50 remarkably decreased after $72 \mathrm{~h}$ compared to $48 \mathrm{~h}\left(P<0.001^{* * *}\right)$ (Fig. 6b). The $4 \mathrm{~T} 1$ cell line after $48 \mathrm{~h}$ of treatment through melittin-loaded niosome (IC50: $75.58 \mu \mathrm{g} / \mathrm{ml}$ ) compared to melittin (IC50: $143.20 \mu \mathrm{g} / \mathrm{ml})$ IC50 was a decrease $\left(P<0.001^{* * * *}\right)$. After $72 \mathrm{~h}$ of treatment, the results showed the melittin-loaded niosome (IC50: $27.17 \mu \mathrm{g} / \mathrm{ml}$ ) compared to melittin (IC50: $40.62 \mu \mathrm{g} / \mathrm{ml})$ was decrease $\left(P<0.001^{* * * *}\right)$ (Fig. 6c). In the SKBR3 cell line after $48 \mathrm{~h}$ of treatment, the results showed the melittin-loaded niosome (IC50: $47.65 \mu \mathrm{g} / \mathrm{ml}$ ) compared to melittin (IC50: $87.87 \mu \mathrm{g} / \mathrm{ml}$ was decreased $\left(P<0.001^{* * *}\right)$. After $72 \mathrm{~h}$ of treatment, the results showed the melittin-loaded niosome (IC50: $31.05 \mu \mathrm{g} / \mathrm{ml}$ ) compared to melittin (IC50: $50.56 \mu \mathrm{g} / \mathrm{ml}$ ) was a decrease $\left(P<0.001^{* * * *}\right)$ (Fig. 6d). Figure 7 shows the cell viability percent of different empty niosome dilutions on MCF10A (a), SKBR3 and $4 \mathrm{~T} 1$ cell lines (b), and cell viability percent of melittin-loaded niosome concentrations on healthy MCF10A cell line (c). The MTT assay was performed, and empty niosome dilutions did not show any significant cytotoxic effects on MCF10A cells separately (Fig. 7a). In Fig. 7b, the empty niosome toxicity was also investigated at different dilutions, and 

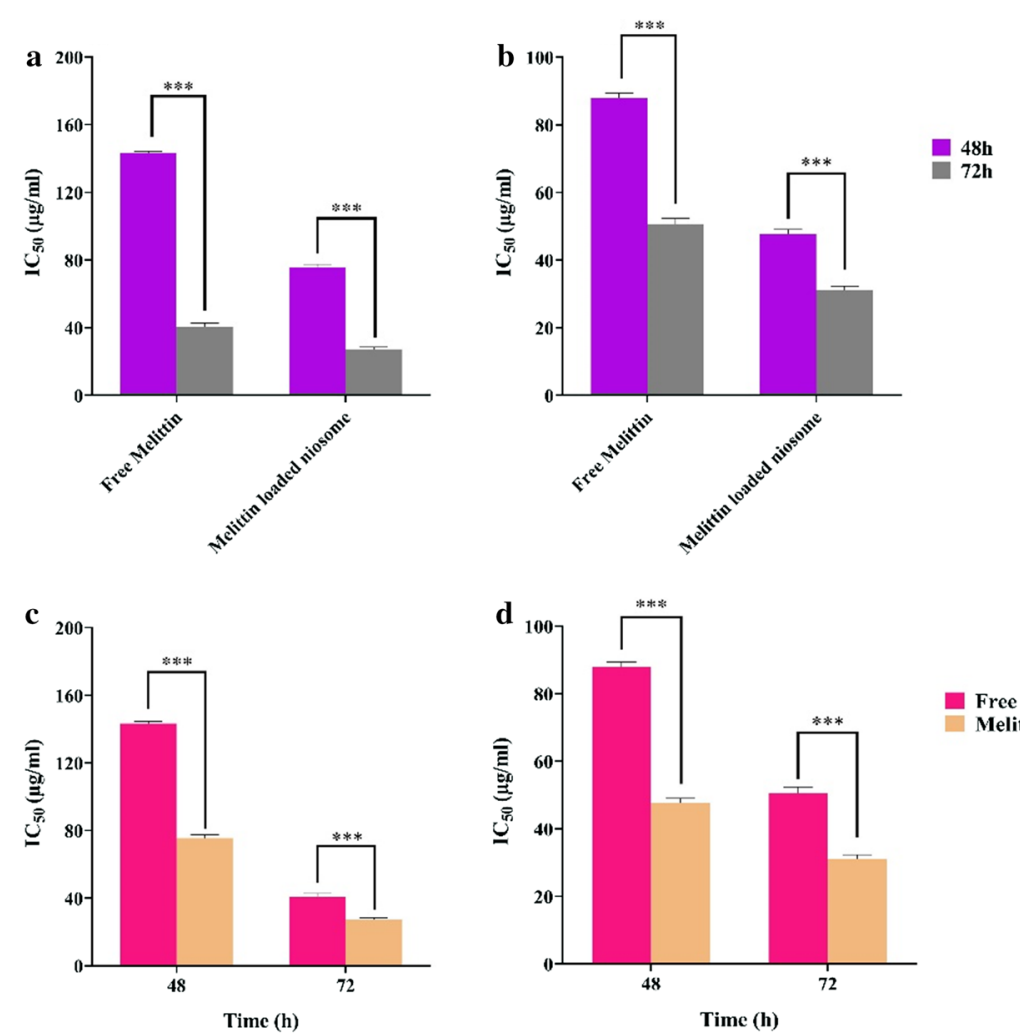

Free Melittin Melittin loaded niosome

Fig. 6 IC50 value in study groups after 48- and 72-h treatment with melittin and melittin-loaded niosome $\left(\mathrm{P}<0.001^{* * *}\right)$ on $4 \mathrm{~T} 1$ cell line (a). IC50 value in study groups after 48 - and 72 -h treatment with melittin, and melittin-loaded niosome $\left(P<0.001^{* *}\right)$ on SKBR3 cell line $(\mathbf{b})$. IC50 value in study groups after 48 - and $72-\mathrm{h}$ treatment with melittin, and melittin-loaded niosome on 4T1 cells with each other $\left(P<0.001{ }^{* * *}\right)(\mathbf{c})$. IC50 value in study groups after 48- and 72-h treatment with melittin, and melittin-loaded niosome on SKBR3 cells with each other $\left(P<0.001^{* *}\right)(\mathbf{d})$. Data are shown as mean \pm SEM. The mean values with different superscript letters are significantly different $(P \leq 0.05)$

it did not showed a statistically significant changes on both cell line viability, and just obsorved statistically significant decrease in $4 \mathrm{~T} 1$ cells [dilution $1 / 4,1 / 2$, and 1 , respectively $\left(P<0.05^{*}, \mathrm{P}<0.05^{*}\right.$, and $\left.\mathrm{P}<0.01^{* *}\right)$. As the melittin-loaded niosome concentration increased, cell viability decreased. So, the 64 , and $128 \mu \mathrm{g} / \mathrm{ml}$ compared to control cell viability was decreased $\left(P<0.01^{* *}\right.$, and $\left.\mathrm{P}<0.001^{* * * *}\right)$ (Fig. 7c). These results indicated that melittin, and melittin-loaded niosome had more cytotoxicity effect on $4 \mathrm{~T} 1$ cells, and as a model for breast mice mammary epithelial cancer cells compared to SKBR3 cell line after $72 \mathrm{~h}$ of treatment. The IC50 concentrations were then utilized to generate fixed ratios for subsequent combination experiments, and the calculation of combination index $(\mathrm{CI})$.

\section{Wound healing assay}

Migration is one of the important characteristics of cancer cells, and promotes cancer metastasis. To determine the effect of melittin, melittin-loaded niosome and empty niosome on migration, invasion, in vitro wound (scratch) assays were performed in 4T1, SKBR3 cells and the wound healing rate was monitored through the complete closure of the scratched. As shown in Fig. 8, cell migration on 4T1, and SKBR3 cell lines 

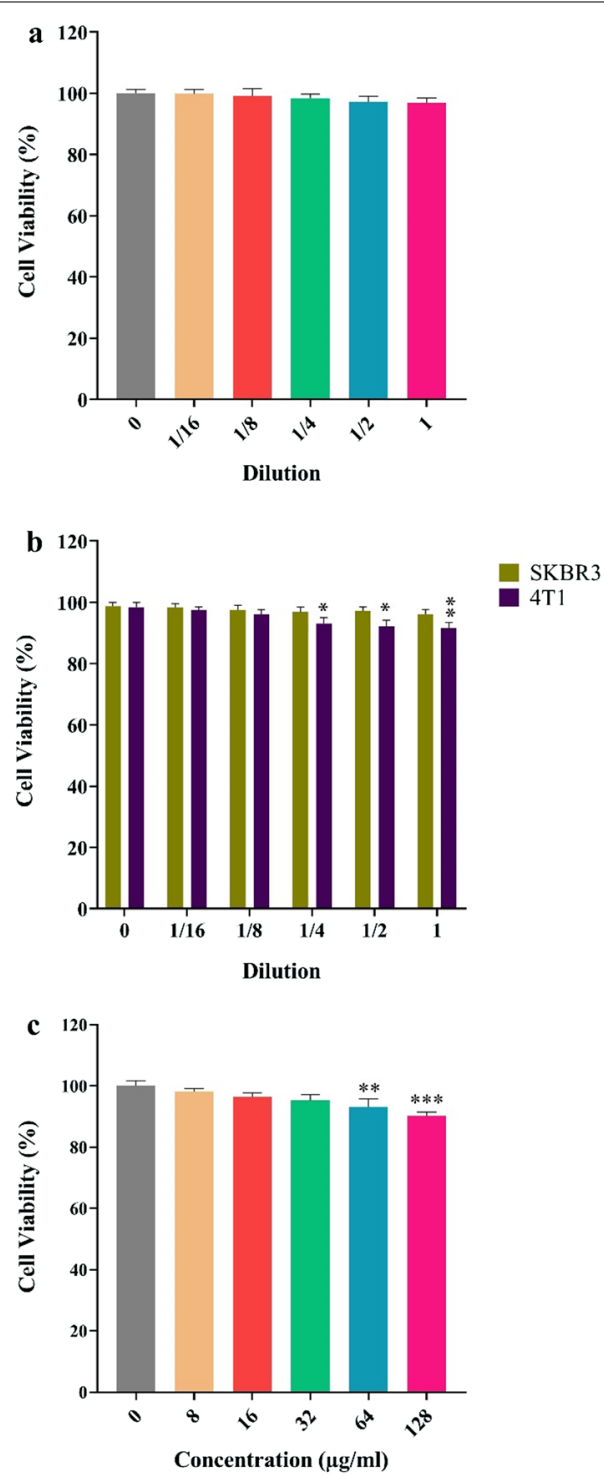

Fig. 7 The figure shows the cell viability percent of different empty niosome dilutions on MCF10A (a), SKBR3 and 4T1 cell lines (b), and cell viability percent of MELITTin-loaded niosome concentrations on healthy MCF10A cell line (c). Data are shown as mean \pm SEM. The mean values with different superscript letters are significantly different $(P \leq 0.05)$

that treatment with melittin-loaded niosome was lower than melittin. Scratch width of SKBR3 cells treated with melittin-loaded niosome $(85.76 \mu \mathrm{m})$ compared to melittin $(65.13 \mu \mathrm{m})$ showed a statistically significant increase $\left(P<0.001^{* * * *}\right)$ (Fig. 8a). Scratch width of 4T1 cells treated with melittin-loaded niosome $(97.41 \mu \mathrm{m})$ compared to melittin $(72.42 \mu \mathrm{m})$ showed a statistically significant increase $\left(P<0.001^{* * * *}\right)$ (Fig. 8b). The scratch width of SKBR3, 4T1 cells treated with empty niosome, respectively (7.34, and $11.21 \mu \mathrm{m})$, melittin, and melittin-loaded niosome were higher than the control $\left(P<0.001^{* * * *}\right)$. 

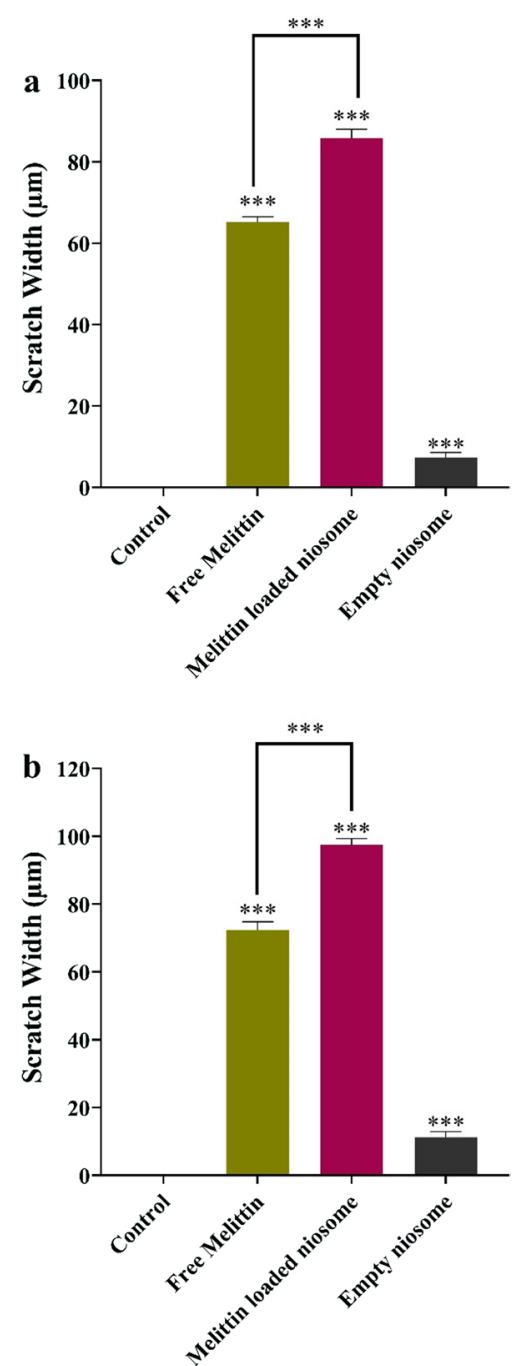

Fig. 8 The inhibitory effects of melittin, melittin-loaded niosome, empty niosome on the migration, invasion of the SKBR3 (a), and 4T1 breast cancer cells $(\mathbf{b})$ after $72 \mathrm{~h}$ of treatment; data are shown as mean \pm SEM. The mean values with different superscript letters are significantly different $(P \leq 0.05)$

\section{Soft agar colony assay}

To further demonstrate the inhibitory effect of melittin, melittin-loaded niosome, and empty niosome on establishment of cancer cell colonies, we performed the soft agar colony formation assay. The number of colones was concentration-dependently decreased by melittin, melittin-loaded niosome, and empty niosome compared to control (Fig. 9). The number of colones in SKBR3 cell line was decreased by treatment with melittinloaded niosome compared to melittin $\left(P<0.001^{* * * *}\right)$ (Fig. 9a). All treatment groups in two cell lines showed a statistically significant decrease $\left(P<0.001^{* * *}\right)$ in number of colony compared to control, and in $4 \mathrm{~T} 1$ cell line the results were the same $\left(P<0.001^{* * *}\right)$ (Fig. 9b). Empty niosome in both cell lines showed a statistically significant decrease compared to control $\left(P<0.001^{* * * *}\right)$. 

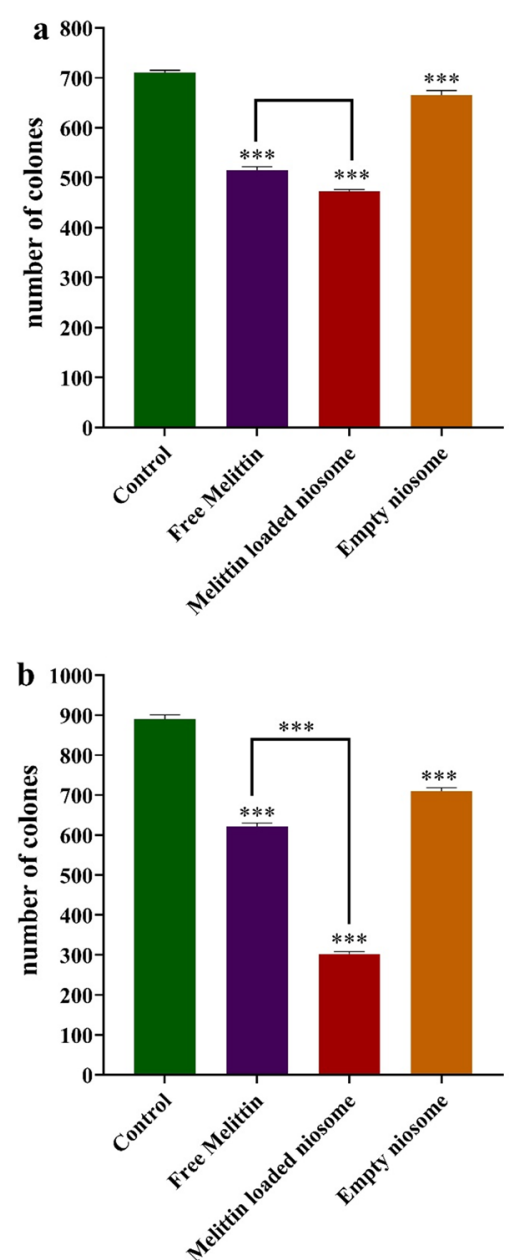

Fig. 9 The inhibitory effects of melittin, melittin-loaded niosome, empty niosome on establishment of SKBR3 (a), and 4T1 (b) cancer cell line colonies after treatment; data are shown as mean \pm SEM. The mean values with different superscript letters are significantly different $(P \leq 0.05)$

\section{Flow cytometric analysis}

Apoptosis of breast cancer cells was measured by double staining using annexin $\mathrm{V}$ fluorescein isothiocyanate (FITC), and propidium iodide (PI). In apoptotic cells, the membrane phospholipid phosphatidylserine (PS) is exposed to the external cellular environment due to translocation from the inner to the outer surface of the plasma membrane. The flow cytometric analysis diagram of melittin, melittin-loaded niosome, empty niosome provided in SKBR3 (Fig. 10a), and 4T1 breast cancer cell lines (Fig. 10b). The results demonstrated that the simultaneous administration total apoptosis of melittin, melittin-loaded niosome, empty niosome (\%) in SKBR3 (Fig. 10a), and 4T1 cell line (Fig. 10b) enhances the total apoptosis in both studied cancer cells. The results showed the groups treated with empty niosome compared to the control group did not show any significant changes in apoptosis rate (\%) in both cell lines. In both cell lines treated by melittin, and melittin-loaded niosome 

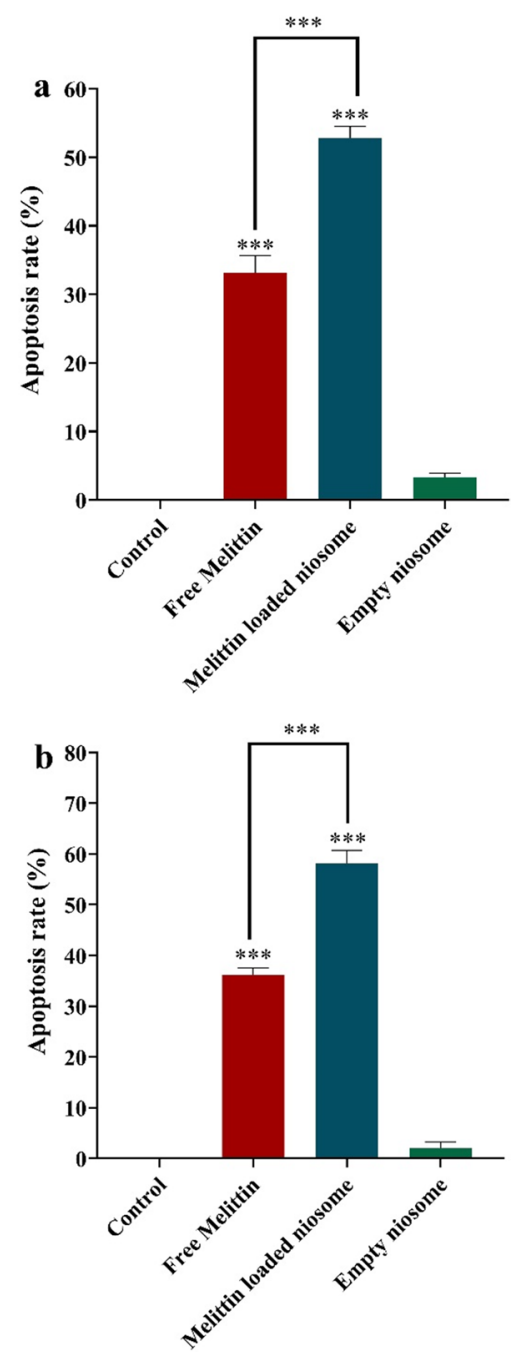

Fig. 10 The inhibitory effects of melittin, melittin-loaded niosome, empty niosome on the apoptosis rate (\%) of the SKBR3 (a), and $4 \mathrm{~T} 1$ breast cancer cells $(\mathbf{b})$ after $72 \mathrm{~h}$ of treatment; data are shown as mean \pm SEM. The mean values with different superscript letters are significantly different $(P \leq 0.05)$

showed a statistically significant increase in the percentage of apoptosis compared to controls $\left(P<0.001^{* * * *}\right)$. In both cell lines melittin-loaded niosome showed a higher apoptosis rate $(\%)$ compared to melittin $\left(P<0.001^{* * * *}\right)$.

\section{Gene expression analysis by real-time PCR}

The inhibitory effect of drugs might be due to regulating the expression level of different genes inside the cells. It has been reported that the melittin, and melittin-loaded niosome could affect the expression level of different genes inside the breast cancer cells. Therefore, the expression of eight different genes (Bax, Bcl2, Caspase3, Caspase9, $M M P 2$, and MMP9) in the two breast cancer cells (4T1, and SKBR3) was measured. Figure 11a shows the expression levels of Caspase3 gene in SKBR3 cell line treated by melittin, melittin-loaded niosome, and empty niosome. According to the figure, melittin-loaded niosome had a higher expression level of Caspase 3 than the melittin group 

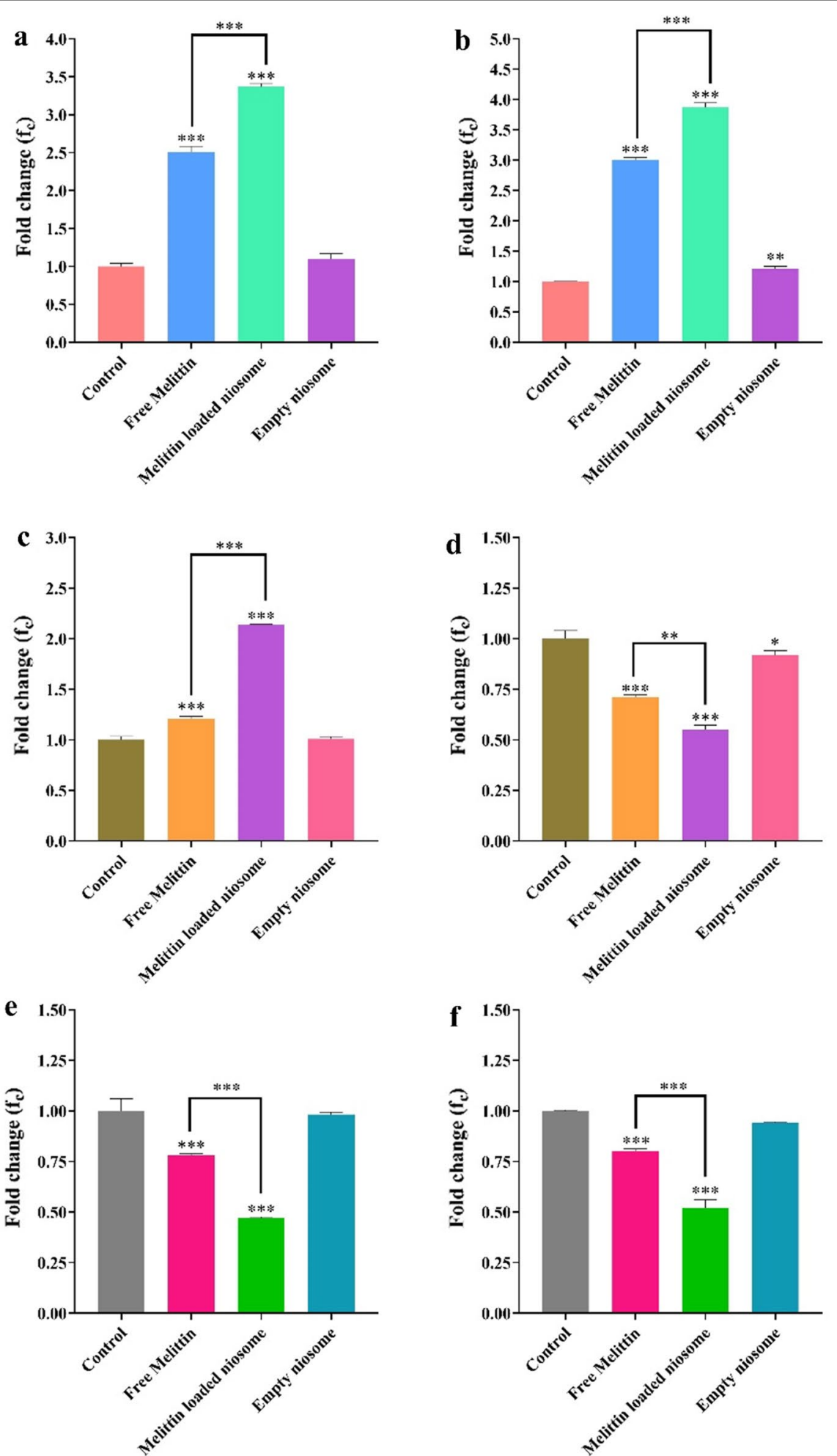

Fig. 11 The expression levels of Caspase3 (a), Caspase9 (b), Bax (c), BCl2 (d), MMP2 (e) MMP9 (f) genes treated by melittin, melittin-loaded niosome, and empty niosome in SKBR3 cell line. Data are shown as mean \pm SEM. The mean values with different superscript letters are significantly different $(P \leq 0.05)$ 
$\left(P<0.001^{* * * *}\right)$. In Fig. 11b, Caspase 9 expression levels in group with melittin-loaded niosome were higher than the melittin $\left(P<0.001^{* * * *}\right)$. The empty niosome also showed a statistically significant increase $\left(\mathrm{P}<0.01^{* *}\right)$ compared to the control group. However, in Fig. 11c melittin-loaded niosome has more Bax expression levels in cells than melittin $\left(P<0.001^{* * *}\right)$. In Fig. $11 \mathrm{~d}$ the $B c l 2$ gene expression level in melittin-loaded niosome was lower than the melittin $(\mathrm{P}<0.01 * *)$. On the other hand, the empty niosome also showed a statistically significant decrease $\left(\mathrm{P}<0.05^{*}\right)$ compared to the control group. As shown in figures related to SKBR3, the decrease $M M P 2$, and $M M P 9$ gene expression levels can be seen in melittin-loaded niosome comparison with the melittin $\left(\mathrm{P}<0.01^{* * *}\right)$ (Fig. 11e, f). The expression levels of Caspase3 (Fig. 12a), and Caspase9 (Fig. 12b) genes in 4T1 cell line treated by melittin-loaded niosome were higher than melittin $\left(P<0.001^{* * * *)}\right)$. The empty niosome also showed a statistically significant decrease Caspase $3\left(P<0.01^{* *}\right)$, and Caspase $9\left(P<0.001^{* * *}\right)$ compared to the control group. Also, indicate the mRNA levels of Bax in 4T1 cells treated by melittin-loaded niosome was increased compare to melittin $\left(P<0.001^{* * *}\right)$, and the empty niosome also showed a statistically significant increase $\left(P<0.01^{* *}\right)$ compare to control (Fig. 12c). The results revealed that melittin-loaded niosome decrease $B c l 2$ expression levels in $4 \mathrm{~T} 1$ cells compared to melittin $\left(P<0.001^{* * * *}\right)$ (Fig. 12d). The decreased $M M P 2$, and $M M P 9$ gene expression levels can be seen in melittin-loaded niosome compared to melittin $\left(P<0.01^{* * * *}\right)$ (Fig. 12e, f).

According to Figs. 11 and 12, the expression levels of Caspase3, Caspase9, and Bax in both cell lines, exposed to all study groups were higher than the control group $\left(P<0.001^{* * * *}\right)$ the expression levels of $B c l 2, M M P 2$, and $M M P 9$ in both cell lines, exposed to all study groups were lower than the control group $\left(P<0.001^{* * * * *}\right)$.

\section{Mice weight, and tumor volume changes}

All animals on the first day of the treatment period had the same weight (about $19 \pm 0.20$ g), and tumor volume $(3 \mathrm{~mm} 3)$, and last day of the experiment, mice weights, and tumor volume showed differences. The weight of groups treated with melittin (3, and $6 \mathrm{mg} / \mathrm{kg})$, and melittin-loaded niosome $(1.5$, and $3 \mathrm{mg} / \mathrm{kg})$ showed statistically significant increase $\left(\mathrm{P}<0.001^{* * * *}\right)$ compared to cancer control. The tumor volume of groups treated with melittin ( 3 , and $6 \mathrm{mg} / \mathrm{kg})$, and melittin-loaded niosome $(1.5$, and $3 \mathrm{mg} / \mathrm{kg})$ showed statistically significant decrease $\left(\mathrm{P}<0.001^{* * * *}\right)$ compared to cancer control. The weights of the groups treated with melittin (3, and $6 \mathrm{mg} / \mathrm{kg}$ ), and melittin-loaded niosome $(1.5$, and $3 \mathrm{mg} / \mathrm{kg}$ ) did not show statistically significant changes compared to each other. The tumor volume of the groups treated with melittin-loaded niosome (1.5, and $3 \mathrm{mg} / \mathrm{kg}$ ) compared to melittin (3, and $6 \mathrm{mg} / \mathrm{kg}$ ) showed statistically significant decrease $\left(\mathrm{P}<0.001^{* * * *}\right)$. Also, the results obtained from the weight, and tumor volume in the group treated with empty niosome were similar to the cancer control group, and the empty niosome did not show any anti-cancer effect on breast tumor. Melittin-loaded niosome $3 \mathrm{mg} / \mathrm{kg}$ showed the greatest effect in inhibiting mice tumor growth, and weight losing (Table 3).

\section{Histopathology}

Histopathological evaluation, and malignancy of breast cancer in the studied samples were showed using pleomorphism, mitosis, and invasion scoring (Table 4). 

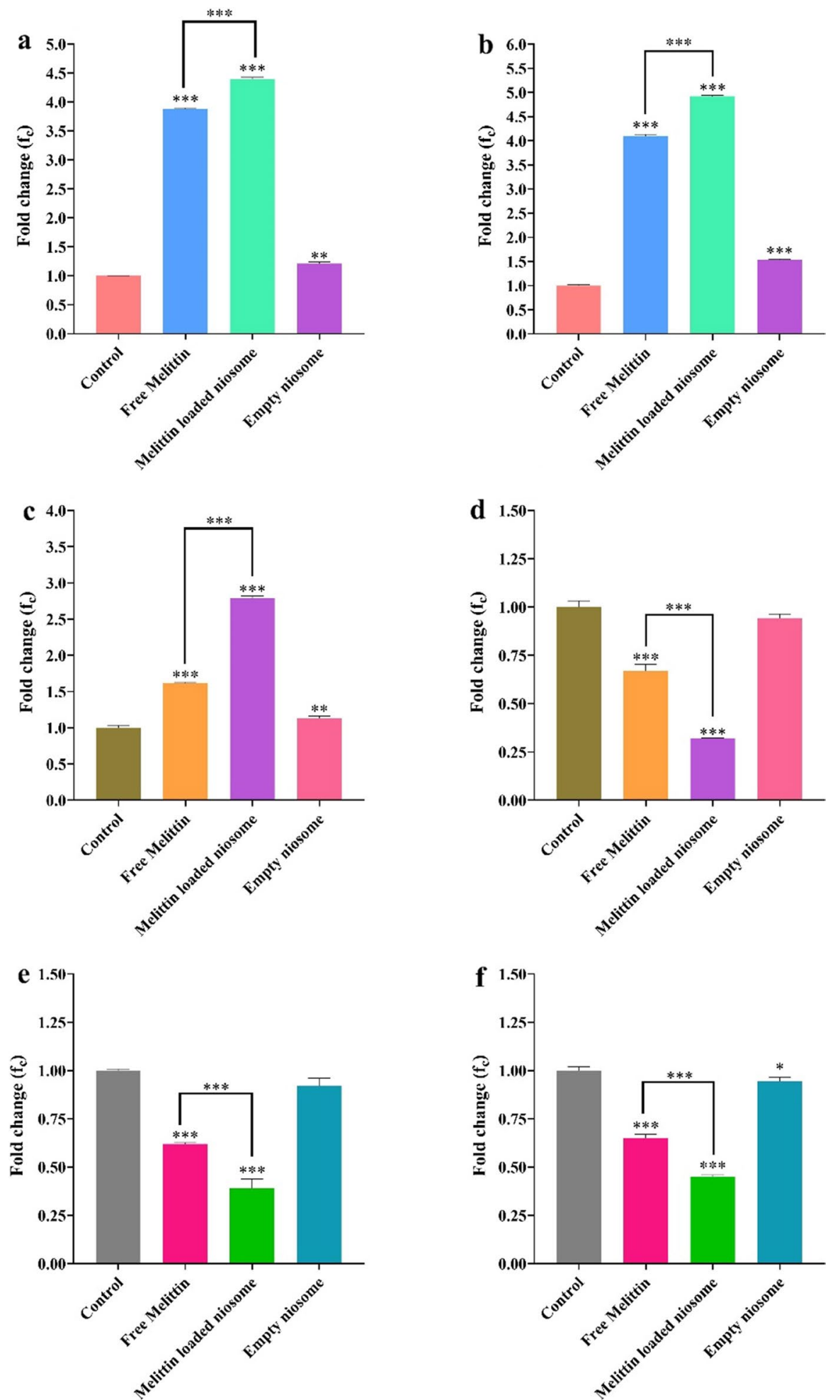

Fig. 12 The expression levels of Caspase3 (a), Caspase9 (b), Bax (c), BCl2 (d), MMP2 (e), and MMP9 (f) genes treated by melittin, melittin-loaded niosome, and empty niosome in 4T1 cell line. Data are shown as mean \pm SEM. The mean values with different superscript letters are significantly different $(P \leq 0.05)$ 
Table 3 Mice weight, and tumor volume changes after 20 days of treatment

\begin{tabular}{lll}
\hline Groups & Last day weight & $\begin{array}{l}\text { Last day } \\
\text { tumor } \\
\text { volume }\end{array}$ \\
\hline Cancer control & & 6.01 \\
Healthy control & 15.50 & 0 \\
Melittin $3 \mathrm{mg} / \mathrm{kg}$ & 21.93 & 5.12 \\
Melittin $6 \mathrm{mg} / \mathrm{kg}$ & 20.12 & 4.78 \\
Melittin-loaded niosome $1.5 \mathrm{mg} / \mathrm{kg}$ & 20.69 & 3.22 \\
Melittin-loaded niosome $3 \mathrm{mg} / \mathrm{kg}$ & 21.13 & 3 \\
Empty niosome $6 \mathrm{mg} / \mathrm{kg}$ & 21.52 & 5.87 \\
\hline
\end{tabular}

Table 4 Clinico-pathological result

\begin{tabular}{llll}
\hline Group & Pleomorphism & Mitosis index & Invasion \\
\hline Cancer control & 3 & 3 & 3 \\
Healthy control & 0 & 0 & 0 \\
Melittin $3 \mathrm{mg} / \mathrm{kg}$ & 3 & 3 & 2 \\
Melittin $6 \mathrm{mg} / \mathrm{kg}$ & 2 & 2 & 1 \\
Melittin-loaded niosome $1.5 \mathrm{mg} / \mathrm{kg}$ & 2 & 2 & 2 \\
Melittin-loaded niosome 3 mg/kg & 2 & 1 & 1 \\
Empty niosome 6 mg/kg & 3 & 3 & 3 \\
\hline
\end{tabular}

In the cancer control group (a), and empty niosome (g) extremely invasive tumor cells in the hypodermis, and underlying muscle layer, severe necrosis at the center of the tumor, and severe pleomorphism, and severe hyperchromatic with high mitosis. Therefore, an empty niosome could not show any anti-breast cancer effects. In healthy control, there are not any cancer cells, and tissue in dermis (b), and the group, with melittin $3 \mathrm{mg} / \mathrm{kg}$ treatment, there are few tumor cells that they are associated with inflammatory cells (c). There is tumor mass beneath the skin, indicates necrotic tissue, and shows the prominent nuclear pleomorphism (d) that was exactly in line with the results of the group treated $3 \mathrm{mg} / \mathrm{kg}$ of melittin. Examination of mammary gland tissue sections that treated with $1.5 \mathrm{mg} / \mathrm{kg}$ of melittin-loaded niosome show a few numbers of tumor cells are found with very low cellular pleomorphism, and fewer inflammatory cells (e). Evaluation of breast tissue sections that treatment with $3 \mathrm{mg} / \mathrm{kg}$ melittin-loaded niosome show a few numbers of tumor cells are found in the skin hypodermis with very low cellular pleomorphism, and fewer inflammatory cells (f) (Fig. 13).

(See figure on next page.)

Fig. 13 Microscopic views of mammary gland adenocarcinoma. H\&E staining of cancer control (original magnification, $\times 400)(\mathbf{a})$; H\&E staining of healthy control (original magnification, $\times 400)(\mathbf{b})$; H\&E staining of melittin $3 \mathrm{mg} / \mathrm{kg}$ (original magnification, $\times 400)(\mathbf{c})$; H\&E staining of melittin $6 \mathrm{mg} / \mathrm{kg}$ (original magnification, $\times 400)(\mathbf{d})$; H\&E staining of melittin-loaded niosome $1.5 \mathrm{mg} / \mathrm{kg}$ (original magnification $\times 400)$ (e); H\&E staining of melittin-loaded niosome $3 \mathrm{mg} / \mathrm{kg}$ (original magnification, $\times 400$ ) (f); H\&E staining of empty niosome $6 \mathrm{mg} / \mathrm{kg}$ (original magnification, $\times 400)(\mathbf{g})$. (N: necrosis/arrowhead: polymorphism/arrow: cancer tissue, and cell mitosis) 

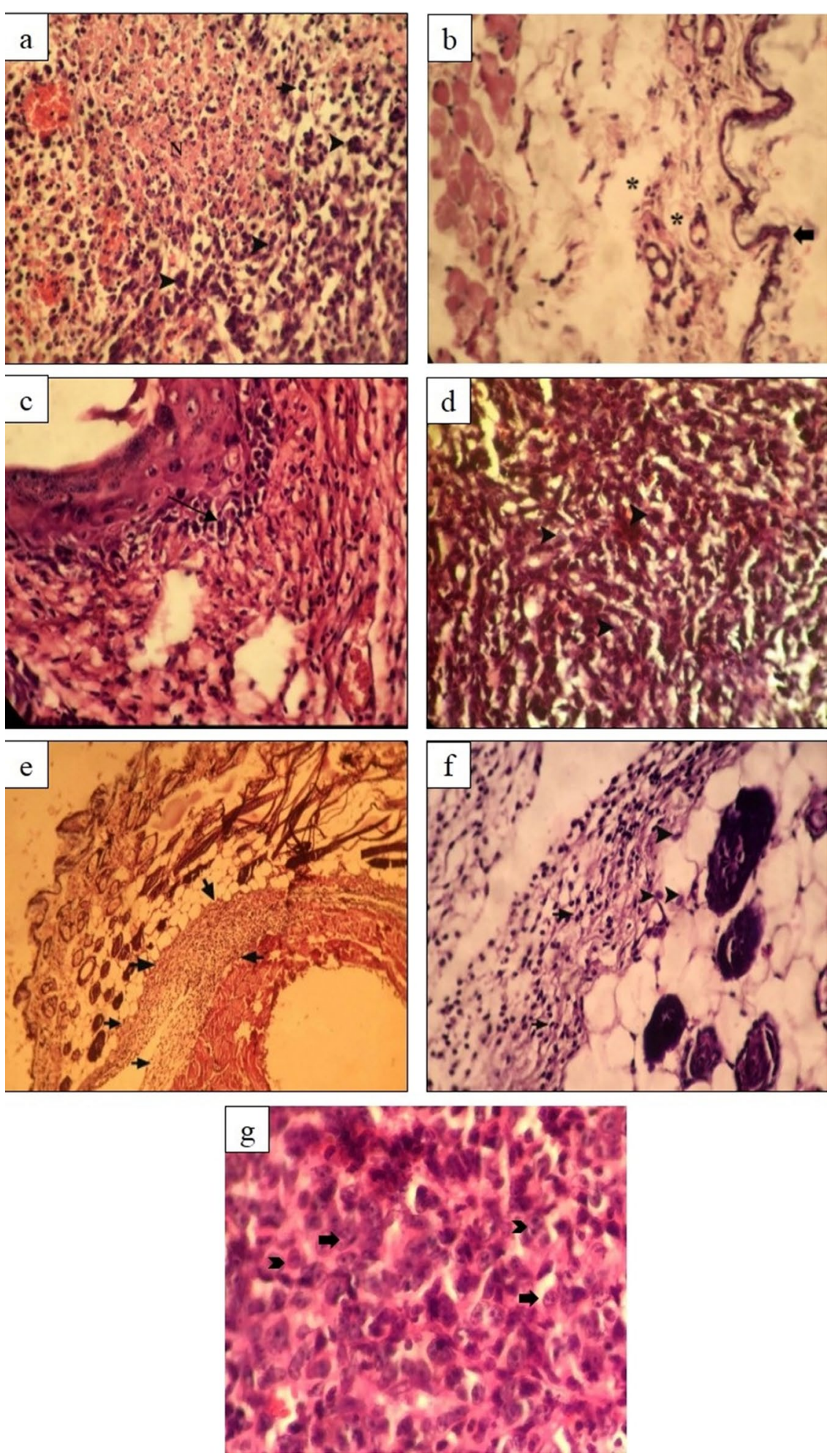
Table 5 Evaluation of serum renal, and liver enzymes activity

\begin{tabular}{llllllll}
\hline Group & BUN & Creatinine & AST & ALT & ALP & Albumin & Total protein \\
\hline Cancer control & 23.65 & 0.6 & 230 & 126.11 & 370 & 2.67 & 4.88 \\
Healthy control & 21.35 & 0.43 & 215.4 & 110 & 295 & 2.95 & 4.95 \\
Melittin $3 \mathrm{mg} / \mathrm{kg}$ & 19.22 & 0.5 & 218 & 115 & 310 & 2.87 & 4.95 \\
Melittin $6 \mathrm{mg} / \mathrm{kg}$ & 21 & 0.44 & 216.11 & 113.13 & 301 & 2.9 & 4.92 \\
Melittin-loaded niosome 1.5 mg/kg & 21.13 & 0.51 & 214.14 & 109.11 & 294 & 2.9 & 4.98 \\
Melittin-loaded niosome 3 mg/kg & 21.02 & 0.43 & 213 & 111.2 & 290 & 2.89 & 4.9 \\
Empty niosome 6 mg/kg & 22.01 & 0.51 & 221.1 & 111.21 & 288 & 2.87 & 4.93 \\
\hline
\end{tabular}

\section{Evaluation of renal, and liver enzymes activity}

Renal serum biomarkers (BUN, and creatinine) were assessed. The results showed the groups treated with melittin, melittin-loaded niosome, and empty niosome compared to the healthy control group did not show any significant changes. In the study of serum liver enzymes (AST, ALT, ALP, albumin, and total protein) the results did not show statistically significant changes than healthy control (Table 5).

\section{P53 immunohistochemical assay}

In this study, we used a $4 \mathrm{~T} 1$ cell line to induce breast cancer in mice. We did not know how much of the P53 gene was expressed by 4T1 cells in mice. On the other hand, with the initial hypothesis that melittin can reduce tumor volume, we decided to study the expression of P53 protein in breast tumors through immunohistochemistry. The P53 was not expressed in the groups treated with melittin, melittin-loaded niosome, and empty niosome (Fig. 14).

\section{Discussion}

Melittin is composed of amino acid residues and melittin's hemolytic activity has been demonstrated, and it is known to have potent hemolytic activity against mammalian and bacterial cells due to its weak cell specificity (Bazzo et al. 1988; Sharon et al. 1999). One of the challenging issues related to the properties of melittin is rapid degradation in the blood and non-specific cellular lytic activity (Pan et al. 2011). Melittin, when injected intravenously, causes severe toxic reactions such as hemolysis (DeGrado et al. 1982), which are a limiting factor for widespread use in cancer therapy. In this study, we used niosome as a melittin nanocarrier due to the structural advantage because in pharmacological studies, one of the most important reasons for the delay in drug delivery to the target cell is the side effects of the biological environment on the drug, which niosome has eliminated by protecting the drug (Baillie et al. 1985), high stability, and longer shelf life (Kumar and Rajeshwarrao 2011; Reddy et al. 2012). Cell uptake for nanocarrier is high (Fu et al. 2016) and nanosystem with controlled-release leads to increased drug residence and stability in the target tissue for a longer time (Xu et al. 2016). Niosome reduces the side effects of the drug, including toxicity and the effect of hemolysis. There was a dramatic increase in breast cancer cells, and reduced side effects (Kanaani 2017; Li et al. 2018). Niosomes effectively inhibit P-glycoprotein (P-gp), resulting in the enhanced bioavailability of anticancer and antiviral drugs (Mahale et al. 2012). Targeted 

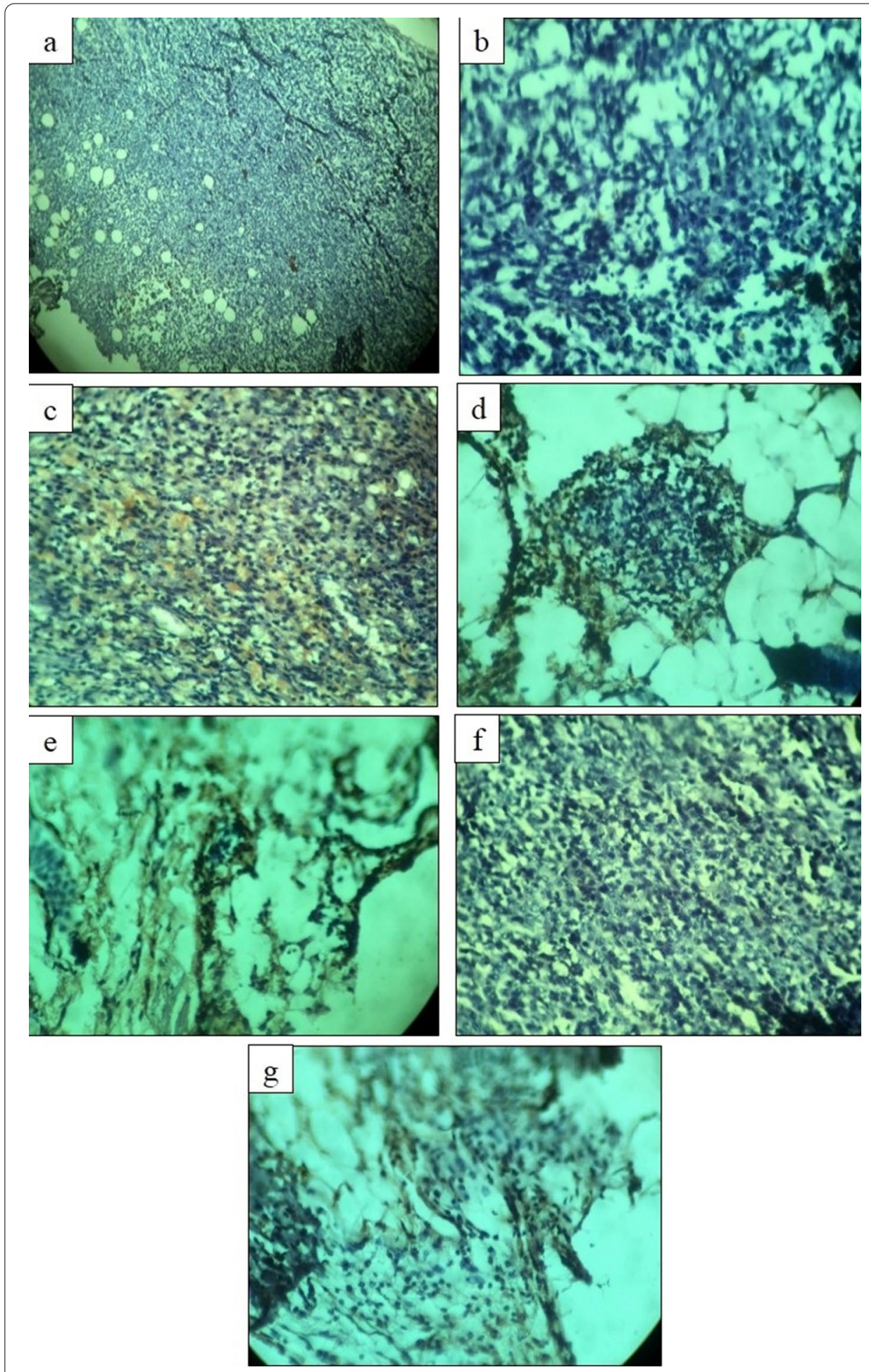

Fig. 14 Immunohistochemistry staining of $P 53$ in mammary gland adenocarcinoma in all experimental groups. Cancer control (original magnification, $\times 40)(\mathbf{a})$; healthy control (original magnification, $\times 40$ ) (b); melittin $3 \mathrm{mg} / \mathrm{kg}$ (original magnification, $\times 40)(\mathbf{c})$; melittin $6 \mathrm{mg} / \mathrm{kg}$ (original magnification, $\times 40)(\mathbf{d})$; melittin-loaded niosome $1.5 \mathrm{mg} / \mathrm{kg}$ (original magnification $\times 40)(\mathbf{e}) ;$ melittin-loaded niosome $3 \mathrm{mg} / \mathrm{kg}$ (original magnification, $\times 40)(\mathbf{f})$; empty niosome $6 \mathrm{mg} / \mathrm{kg}$ (original magnification, $\times 40)(\mathbf{g})$ 
nano-niosomes can selectively deliver melittin to cancer cells through the hemifusion mechanism (Sorge et al. 1999). In one study, melittin-loaded niosome purposefully showed a higher cytotoxic effect than the melittin with more stability and longer shelf life (Li et al. 2018). Melittin-loaded niosome and its effect on breast cancer cells in the study of previous researchers did not show any hemolytic effect (Kanaani 2017) which the results of the present study were consistent with them. In the present study, due to the effect of melittin hemolysis, we used niosome nanoparticles and according to the results, we did not see any hemolytic effect in this structure compared to the melittin. The use of designed nanocarriers and the loading of melittin in them led to the improved of the anti-cancer function of melittin by inhibiting the proliferation of breast cancer cells MDA-MB-231 and MCF-7 (Misra et al. 2015). Also, the use of immunoliposomes containing melittin could reduce the survival of cancer cells in breast tumors with high HE $R^{2}$ expression (Barrajón-Catalán et al. 2010). The development of an environmentally sensitive melatonin delivery system, dual safe nanostructure (DSNS) led to the safe transfer of melittin to cancer cells, which is very effective in killing MCF-7, HCT-116, SKOV-3 and NCI/ADR-RES cells. It was more efficient than its free form and had no hemolytic effect (Cheng et al. 2015). Melittin was delivered using the nanoconjugates to target and kill syngeneic (B16F10 mouse melanoma), xenograft (MDA-MB-435 human breast cancer) and precancerous lesions in K14-HPV16 mice with squamous dysplasia and carcinoma (Soman et al. 2009). The favorable pharmacokinetic structure of the nanocarrier allows melittin to be deliberately delivered in mouse tumors in vivo and reveals a significant reduction in tumor growth without signs of toxicity. Also, the use of Perfluorocarbon nanoparticles and melittin-loaded in them in a targeted manner led to the targeted delivery of melittin in a mouse model of melanoma and significantly reduced tumor growth rate (Jallouk et al. 2015). Therefore, due to the successful results of our previous researchers in this study, we used the structure of nano-systems for specific and targeted transfer of melittin to breast cancer cells. Our results, according to previous reports, showed that the percentage of hemolysis effect on mice erythrocytes in the groups treated with empty niosome and melittin-loaded niosome that showed significantly reduced, while the increase in hemolysis was quite evident in the groups treated with melittin.

The first study to prove the cytotoxic effect of melittin on tumor cells was performed in 1985 (Hait et al. 1985). Melittin can inhibit calmodulin, calcium pump activity, leading to an increase in intracellular calcium, a process that is toxic to cells, and leads to death (Hait et al. 1985). Several studies have shown similar results, including that increased intracellular $\mathrm{Ca} 2+$ concentration can be induced through activation of L-type $\mathrm{Ca} 2+$ channels (Chu et al. 2007). Melittin is effective on intracellular $\mathrm{Ca} 2+$ mobilization, and exocytosis through various independent signaling pathways (Ryu et al. 2014). As intracellular calcium increases, regulation of the expression of genes involved in cell death occurs, including increased Bax gene expression, decreased Bcl2 gene expression, cell death occurs, and leading to increase caspase 3 and 9 expressions (Rady et al. 2017). In general, reports confirm that melittin increases intracellular $\mathrm{Ca} 2+$ concentrations, and exerts cytotoxic effects on cells. On the other hand, melittin is an amino acid chain with the chemical formula $\mathrm{C} 131 \mathrm{H} 229 \mathrm{~N} 39 \mathrm{O} 31$, one of the most important activities of which is its very strong hemolytic property (Badria et al. 2017). In the N-terminal region 
of the melittin structure, most amino acids (the first 20 substances) are hydrophobic, while in the C-terminal region, they are mainly composed of hydrophilic agents (Vogel and Jähnig 1986), which allows this amphipathic structure. Melittin can interact successfully with the phospholipid membranes of cells (Malekzadeh et al. 2009). Melittin acts as a non-selective cytolytic peptide, physically, chemically disrupts all prokaryotic, and eukaryotic cell membranes (Adade et al. 2013; Do et al. 2014; Shi et al. 2016; Skalickova et al. 2015). Melittin binds to the surface of the negatively charged membrane structure then by forming pores in the membrane surface leads to leakage of ions, atomic molecules, and increased permeability, which ultimately leads to cell lysis and disrupts the integrity of the phospholipid bilayer (Jamasbi et al. 2016). Melittin has become a desirable candidate for chemotherapy, which causes more damage to the tumor cell membrane because its membrane potential is higher, and the cells are less resistant to the formation of membrane pores (Schweizer 2009; Soman et al. 2008). Melittin exemplifies this large class of membrane-active peptides that manifest membrane-disrupting activity when incorporated into traditional bilayer delivery systems (i.e., liposomes) (Bechinger 1997; Tosteson and Tosteson 1981). Melittin's action is physical and chemical disruption of membrane structure resulting in profound compromise of the cell permeability barrier by lysis (DeGrado et al. 1982; Tosteson and Tosteson 1981; Lee et al. 2004; Yang et al. 2001). The peptide partitions into the cell membranes as a monomer, followed by oligomerization into toroidal or barrel stave structures that facilitate pore formation to effect cell death (Soman et al. 2009; Lee et al. 2008). Melittin has important anti-cancer effects on various types of cancers, including breast cancer so nanocarrier allows accumulation of melittin in murine tumors in vivo, and a dramatic reduction in tumor growth without any apparent signs of toxicity since nanocarriers selectively delivered melittin to multiple tumor targets, including cancer cells (Soman et al. 2009; Lee et al. 2008). In another study, the synergistic co-delivery of doxorubicin, and melittin using $f$ nanoparticles for cancer treatment in LC-MS/MS indicated that the co-delivery system of doxorubicin-melittin-loaded CA-MNPs is highly capable of being used in magnetically targeted cancer therapy (Hematyar et al. 2018). Melittin nano-liposomes would have a better application in hepatocellular carcinoma cells (HCC) therapy due to induced apoptosis in hepatic carcinoma cells in vitro, in vivo and inhibit hepatocellular carcinoma in LM-3 xenograft tumor model (Mao et al. 2017). Melittin inhibited the vascular endothelial growth factor migration of non-small cell lung cancer cells, when compared with the control group (Zhang and Chen 2017). The development of most human cancers, primary cells move out, invade the neighboring tissues, and ultimately travel to distant sites to make new colonies, so targeting cancer cell migration, invasion is an important, and necessary aspect of cancer chemotherapy (Yu et al. 2018; Putri et al. 2020). Breast cancer cell invasion and growth of tumor cells can be inhibited by melittin (Park et al. 2010). Combination therapy with anticancer drugs has is a well-known approach in cancer treatment. Plant-derived drugs are desired for anticancer treatment as they are secure, accessible, and also when are combined with anti-cancer agents, they can exert synergistic therapeutic effect, decrease the doses, toxicity, and drug resistance of chemotherapeutic agents (Chou 2010). Hesperidin (Choi 2007; Palit et al. 2015), piperine (Deng et al. 2016), BV, and melittin (Ip et al. 2008; Jang et al. 2003) have also shown to induce apoptosis activity on breast cancer cells. In this study, we also observed 
inhibition of 4T1, and SKBR3 cancer cells migration and invasion in melittin-loaded niosome group. Based on in vivo, and in vitro studies, the results showed that melittin by affecting signal transduction, and regulatory pathways, led to various mechanisms of cancer death, including inhibition of proliferation, induction of apoptosis, inhibition of angiogenesis, cell cycle cessation, and motility inhibition, migration, metastasis, and invasion of cancer (Soman et al. 2008). Melittin plays an important role in activating the executive caspases of various cells, including leukemia U937 (Moon et al. 2008), Jurkat (Wang et al. 2009), HCC (SMMC-7721, Hep3B, HepG2, and BEL-7402) (Wang et al. 2009) cells, prostate PC-3, LNCaP, DU-145 (Park et al. 2011), and cervical HeLa (Wang et al. 2009) cells. Melittin leads to the death of cancer cells by activating death receptors by increasing the expression of DR3, DR4, and DR6 as well as inhibiting the JAK2/ STAT3 pathway [8). The results of another study showed that melittin leads to apoptosis in cancer cells by regulating the signaling pathway of AKT, decreasing Bcl2 gene expression, increasing Bax gene expression, and subsequently increasing caspase 3 , and 9 activity (Moon et al. 2008). Melittin can also induce apoptosis in the HCC cell line by activating $\mathrm{Ca} 2+/$ calmodulin-dependent protein kinase, transforming growth factor-beta-activated kinase 1 (TAK1), and JNK/p38 MAPK (Wang et al. 2009) .As a result, melittin can show its anti-cancer effects by causing primary apoptosis, induction of ROS activity, and caspase 3 activity. Also, by activating the mitochondrial pathway, melittin increases cytochrome C, EndoG, and decreases AIF, which are essential in regulating increased Bax gene expression, and decreased Bcl2 gene expression, and ultimately occurs with increased caspase 3, and 9 apoptosis (Saini et al. 1999). The results of a study performed on MG63 osteosarcoma cells showed that melittin causing Ca2+entry through L-type $\mathrm{Ca} 2+$ channels in a manner independent of protein kinase-C, and phospholipase A2 activity, and this $\mathrm{Ca} 2+$ increase subsequently caused apoptosis (Chu et al. 2007). Melittin also inhibits the proliferation of MG63 cells by activating the ER stressmediated apoptotic pathway, in which activation of the IRE- $\alpha$ pathway is mediated by CHOP protein expression (Fan et al. 2014). Melittin has the effects of angiogenesis, invasion, and necrosis, which led to the suppression of HIF-1 $\alpha$ /VEGF expression by inhibiting ERK, and mTOR/p70S6K pathways in CaSki cells of human cervical cancer (Shin et al. 2013) (Fig. 1). The apoptotic rates of human thyroid cancer cell line (TT) cells were increased following melittin treatment, melittin causes increased Caspase3, Caspase9, Bax, and inhibited B-cell lymphoma 2 genes, and protein expression (Wan 2018). Melittin decreased the invasion rate of MCF-7 human breast cancer cell line by down-regulating CD147, and MMP-9 by inhibiting cyclophilin A expression so the results provide evidence for melittin in anticancer therapy, and mechanisms (Wang et al. 2017). Honey bee venom contains melittin and chrysin which are effective in destroying chemo-resistant ovarian cancer cells through up-regulation of Caspase3, Caspase9, and down-regulation of $B c l 2$ gene expression (Amini 2015). In the present study the administration of melittin shows the synergic, and higher up-regulating effects in (Bax, Caspase3, and Caspase 9 genes), and down-regulating (Bcl2, MMP2, and MMP9 genes) in both cell lines.

The efficacy of melittin-loaded niosome was evaluated in immunocompetent mice. Syngeneic B16F10 mouse melanoma tumors in C57BL/6 mice actively secrete angiogenic growth factors, and have already developed a vascular supply (Culp et al. 2006). 
Synthetic nanoscale vehicles such as nanoparticles can deliver a model cytolytic peptide (melittin) by flexible passive, and active molecular targeting to kill established solid tumors, and precancerous lesions (Soman et al. 2009). Our results consistent with previous reports showed the melittin-loaded niosome can significantly inhibit nuclear pleomorphism, mitosis, invasion of breast cancer cells, and had anti-cancer effects compared to melittin, and cancer control. Also, the melittin $6 \mathrm{mg} / \mathrm{kg}$ was able to show inhibitory effects on pleomorphism, mitosis, and invasion of breast cancer cells compared to the cancer control group but these effects were lower than the melittin-loaded niosome. Melittin is beneficial for the prevention of acute hepatic failure in antitubercular druginduced hepatoxicity through regulation of AST,ALT, ALP, BUN, and Total bilirubin (Naji 2020). The results of the present study were consistent with previous researchers, melittin, and melittin-loaded niosome have not toxicity effect on renal, and liver organs.

P53 is the most important tumor suppressor gene, and codon 72 polymorphism has been identified as a risk factor. Mutation of the P53 gene is seen in $20-40 \%$ of breast cancers. DNA damage causes phosphorylation of the P53 protein, and its accumulation in the cell nucleus. On the other hand, P53 is a prognostic factor in cancer, and the higher P53 expression level can increase the patient's chances of survival (Basu and Haldar 1998). A larger study is needed to further investigate the role of another factor as an independent prognostic factor in breast cancer. Taken together, these findings present new possibilities for melittin treatment in tumor therapy. Although further studies are required to understand the detailed mechanisms of interactions, the data presented here indicate that melittin-loaded niosome can be used as an anticancer therapy, and represents a promising new approach.

\section{Conclusion}

The presented study was aiming for adequate, more effective, and less harmful breast cancer treatment. Our study successfully declares that melittin-loaded nano-niosome properly functions under the ideal-estimated status. This project has demonstrated that niosomes are suitable vesicle carriers for combining drugs, particularly melittin. Melittin-loaded niosome reported had strongly higher anti-cancer effects in vivo, and in vitro than free melittin. Hopefully, this formulation can be industrialized in the next few years and reduces the breast cancer incidence rate.

\section{Methods}

\section{Chemicals}

Melittin was bought from Sigma Aldrich (Germany). Cholesterol, Span 60, Tween 60, and Dialysis membrane (MWCO $12 \mathrm{kDa}$ ) were bought from Sigma Aldrich (USA). Chloroform, Amicon (Ultra15-Membrane, MWCO $30 \mathrm{kDa}$ ), dimethyl sulfoxide (DMSO), ketamine, diazepam and saline were purchased from Merck (Germany). Medium RPMI1640, DMEM (Dulbecco's Adjusted Eagle Medium), trypsin-EDTA, trypan blue, fetal bovine serum (FBS), phosphate-buffered saline (PBS), MTT (dimethylthiazol-2-yl-)-2,5, and penicillin/streptomycin (PS)100 X were attained from Gibco, (USA). Pasteur Institute, Iran, provided the 4T1 murine mammary carcinoma, and SKBR3 human mammary carcinoma. Annexin V-FITC Flow Cytometry kit was obtained from Affymetrix biosciences (USA). Transgene Biotech, China (Cat No. ER101-01, and AE301-02) has 
traded RNA Extraction and cDNA Synthesis kits. Pars Azmoon kit (Iran) to the estimation of the liver, and renal biomarkers activity.

\section{Melittin-loaded niosomes preparation}

"Thin-layer hydration method" prepared the drug-loaded niosomes containing cholesterol, Span 60, and Tween 60, reported in our previous work with minor modifications (Akbarzadeh et al. 2021, 2020). Briefly, surfactants, and cholesterol were dissolved in $10 \mathrm{~mL}$ chloroform as the organic solvent. A rotary evaporator $\left(120 \mathrm{rpm}, 60^{\circ} \mathrm{C}, 1 \mathrm{~h}\right)$ was used to evaporate the chloroform (Heidolph Instruments, Germany). Then, the dried thin films were hydrated utilizing melittin solution (in PBS, $10 \mathrm{~mL}, \mathrm{pH} 7.4$ ) at $60^{\circ} \mathrm{C}$ for one hour (120 rpm). Finally, the sample was sonicated for $5 \mathrm{~min}$ (Hielscher up $50 \mathrm{H}$ ultrasonic processor, Germany, Amplitude: $25 \%, 200 \mathrm{w}$ ) to obtain the niosomal formulations with uniform size distribution (Table 1$)$. The samples were kept in a refrigerator $\left(4{ }^{\circ} \mathrm{C}\right)$ for further experiments.

\section{Morphology, size, and polydispersity of index measurements}

Malvern Zeta Sizer (Malvern Instrument Ltd. Malvern, UK) was applied to distribute the size, and polydispersity index based on dynamic light scattering (DLS). To investigate the optimum formulation morphology, TEM at $80 \mathrm{kV}$ (Netherland, Philips CM30), SEM (SSX-500, Shimadzu, Japan) were utilized.

\section{Determination of encapsulation efficiency (EE)}

The niosomes were ultra-filtered for $20 \mathrm{~min}$ at $4000 \times g$, utilizing an Amicon. During filtration, free drugs moved through the filter membrane, and the niosomal melittin remained in the top chamber. Drug concentration at a wavelength of maximum absorbance peak of the drug molecule was analyzed by UV/visible spectroscopy (JASCO, V-530, Japan), and drug concentration was evaluated according to its standard curve. Finally, the encapsulation efficiency estimated using the following equation:

$$
\text { Encapsulation efficiency }(\%)=[(\mathrm{A}-\mathrm{B}) / \mathrm{A}] \times 100 \text {, }
$$

In this equation, "A" is the amount of initial drug trapped into the niosomal formulations, and "B" stands for non-niosomal-loaded drugs released from the membrane.

\section{In vitro drugs release kinetic study}

The in vitro melittin release from niosomes was analyzed through the following method. Briefly, $2 \mathrm{ml}$ of each sample was added to a dialysis bag. The dialysis bag with each sample was put in PBS solution $(\mathrm{pH}=5.4,6.5,7.4)$, and stirred at $37^{\circ} \mathrm{C}(50 \mathrm{rpm})$. Then Aliquots were taken at specified intervals, and the medium was refreshed. Several kinetic models were investigated and analyzed the release profile.

\section{Niosome stability studies}

The stability was assessed by keeping the optimum formulation containing the niosomal melittin formulation in two different storage conditions $\left(25 \pm 1{ }^{\circ} \mathrm{C}\right.$ (room temperature), and $4 \pm 1{ }^{\circ} \mathrm{C}$ (refrigeration temperature)/60\% $\mathrm{RH} \pm 5 \% \mathrm{RH}$ ) for two months. The physical 
properties accounted for vesicle size (nm), polydispersity index (PDI), and entrapment efficiency (\%) was evaluated at certain time intervals $(0,14,30$, and 60 days).

\section{Hemolytic activity assay}

Red blood cell hemolysis was considered for measuring the bioactivity of melittin based on the revised protocol. One BALB/c inbred mouse anesthetized intraperitoneally $(200 \mu \mathrm{l})$ by an anesthetic combination of ketamine, diazepam and saline (6:9:10) before cardiac puncture sampling. Using centrifugation $\left(1,500 \mathrm{rpm}, 5 \mathrm{~min}, 4{ }^{\circ} \mathrm{C}\right)$, their Red Blood Cells (RBCs) were isolated from the fresh blood sample $(\sim 800 \mu \mathrm{l})$. After centrifugation, isolated RBCs were washed by sterile PBS until the supernatant became clear and then resuspended in $2 \mathrm{ml}$ of sterile PBS. The supernatant was discarded and PBS was added to prepare a RBC suspension ( $2 \%, \mathrm{v} / \mathrm{v}) .8,4,2,1,0.5,0.25$ and $0.125 \mu \mathrm{g} / \mathrm{ml} \mathrm{sam-}$ ples of melittin, empty niosome, and melittin-loaded niosome 4 and $8 \mu \mathrm{g} / \mathrm{ml}$ were used. PBS was applied as the negative control, whereas Triton X-100 (1\%) was employed as the positive control. Incubation $\left(37^{\circ} \mathrm{C}\right.$ for $2 \mathrm{~h}$ ) of the plate was done followed by centrifugation at $3000 \times \mathrm{rpm}$ for $10 \mathrm{~min}$. A 96-well plate was employed to transport $100 \mu \mathrm{l}$ of the supernatant. The optical density (OD) was determined at $540 \mathrm{~nm}$ through a microplate spectrophotometer (Epoch-Biotek; USA). The hemolysis percentage was obtained via the below formula: hemolysis $(\%)=($ OD576sample-OD576negative control) / (OD576positive control-OD576negative control) $\times 100 \%$.

\section{Cell culture}

The mouse breast epithelial 4T1, and SKBR3 cell line purchased from Pasteur Institute Cell Bank, Iran. Tehran. The cell line was cultured at $37{ }^{\circ} \mathrm{C}$, and in a $5 \% \mathrm{CO} 2$ in an air atmosphere. All cells tested negative for mycoplasma contaminations and were markedly cultured in fresh medium (RPMI1640) supplemented with $10 \%$ FBS, and $1 \%$ antibiotics (penicillin/streptomycin). The culture medium was replaced every $48 \mathrm{~h}$. Once the cells reached $90-95 \%$ confluency, the medium was aspirated, and the cells monolayer was washed three times with sterile phosphate-buffered saline. The cell monolayer was treated with $1 \mathrm{ml}$ of $0.25 \%(\mathrm{w} / \mathrm{v})$ trypsin-EDTA, incubated briefly at $37{ }^{\circ} \mathrm{C}$, and visualized microscopically to ensure complete cell detachment. Cells were re-suspended in a complete growth medium. Cells were also stained with trypan blue (100 $\mu \mathrm{l}$ of cell suspension, and $100 \mu \mathrm{l}$ of $0.4 \%$ trypan blue), incubated for $2 \mathrm{~min}$ at room temperature, and counted using a hemocytometer.

\section{Cell proliferation assay}

4T1 and SKBR3 cell lines were separately seeded in a 96-well plate at a density of $5 \times 105$ /well including RPMI 1640 medium supplemented with $10 \% \mathrm{FBS}$, and $1 \%$ penicillin/streptomycin, and $2 \% \mathrm{~L}$-glutamine. Cells were incubated under an atmosphere of $95 \%$ air at $37{ }^{\circ} \mathrm{C}$, and $5 \% \mathrm{CO} 2$ for $24 \mathrm{~h}$ reaching $70-80 \%$ confluence. $8,16,32,64,128$, and $256 \mu \mathrm{g} / \mathrm{ml}$ concentrations of melittin, and melittin-loaded niosomes were added, and cells were incubated for 48 , and $72 \mathrm{~h}$. Moreover, various dilutions of empty niosome were added on 4T1, SKBR3, and MCF10A cell lines, and incubated for $72 \mathrm{~h}$. Incubation of the cells with $0.5 \mathrm{mg} / \mathrm{ml}$ of MTT was performed for $4 \mathrm{~h}$ followed by replacing the 
Table 6 The primer sequences used in real-time polymerase chain reaction

\begin{tabular}{|c|c|c|}
\hline Genes & Forward primer $\left(5^{\prime}-3^{\prime}\right)$ & Reverse primer $\left(3^{\prime}-5^{\prime}\right)$ \\
\hline Bax & CGGCAACTTCAACTGGGG & TCCAGCCCAACAGCCG \\
\hline$B C / 2$ & GGTGCCGGTTCAGGTACTCA & TTGTGGCCTTCTTTGAGTTCG \\
\hline Caspase3 & CATACTCCACAGCACCTGGTTA & ACTCAAATTCTGTTGCCACCTT \\
\hline Caspase9 & CATATGATCGAGGACATCCAG & TTAGTTCGCAGAAACGAAGC \\
\hline MMP2 & TTG ACG GTA AGG ACGGAC TC & CAT ACT TCA CAC GGA CCA CTTG \\
\hline MMP9 & GCACGACGTCTTCCAGTACC & CAGGATGTCATAGGTCACGTAGC \\
\hline B-actin & TCCTCCTGAGCGCAAGTAC & CCTGCTTGCTGATCCACATCT \\
\hline
\end{tabular}

medium with $100 \mu \mathrm{l}$ of DMSO, and vortexing for $20 \mathrm{~min}$. A microplate reader was used to measure the absorbance $(570 \mathrm{~nm})$. Median inhibitory concentration (IC50) was calculated for samples.

\section{Soft agar colony assay}

4T1 and SKBR3 cells treated with melittin, melittin-loaded niosome, and empty niosome were suspended in 0.35\% agarose, and RPMI 1640 supplemented with 20\% FBS and seeded over a basal layer of $0.5 \%$ agarose. The experiments were established in 100 $\mathrm{mm}$ Petri dishes at a cell density of $6 \times 103$ cells/well. Colonies were manually counted in nine random fields after 21 days of culture at $37^{\circ} \mathrm{C}$. Phase-contrast micrographs of the colonies were captured with an Olympus (Tokyo, Japan).

\section{Wound healing assay}

To study cell migration, 4T1, and SKBR3 cancer cells were seeded at 5-105 cells/well in 24-well plates, and incubated until they reached $70 \%$ confluence. Monolayers were scratched with a $200 \mu$ l pipette tip to create a wound, and cells were then washed twice with serum-free culture media to remove floating cells. Media were replaced with fresh serum-free medium. Cells were incubated in IC50 concentration of melittin, melittinloaded niosome, and empty niosome in the medium for $72 \mathrm{~h}$. Then cells were washed with PBS, fixed, and microscopic photos were made.

\section{Flow cytometric analysis}

To further determine apoptosis induction of 4T1, and SKBR3 cells were stained with Annexin-V/PI assay, followed by flow cytometry, and were compared with cells treated with melittin, melittin-loaded niosome, and empty niosome. The flow cytometric analysis indicated a significant induction in the percentage of apoptosis rate in both groups of cells treated with IC50 of melittin and melittin-loaded niosome. Annexin V could be served as a sensitive probe for the flow cytometric analysis of cells undergoing apoptosis due to its high affinity for PS, even when it conjugated with FITC. Furthermore, PI can stain the DNAs in the flow cytometry due to its intercalating property. PI stains the dead cells as it cannot penetrate the membrane of live cells and apoptotic cells. Therefore, it is useful to differentiate necrotic, apoptotic, healthy, and dead cells.

To evaluate the apoptosis ratio, the 4T1, and SKBR3 cells were treated with melittin, melittin-loaded niosomes, and empty niosome IC50 concentration for $72 \mathrm{~h}$, and then the 
cells were studied using Annexin V/propidium iodide (PI) assay, according to the manufacturer's instructions. Briefly, cells were two times washed using cold PBS followed by resuspending in $1 \mathrm{X}$ binding buffer $(5 \times 105$ cells/ well $)$. A culture tube $(5 \mathrm{ml})$ was then filled with $100 \mu \mathrm{l}$ of the solution. The tubes were then filled with FITC Annexin V, and PI (each $5 \mu \mathrm{l})$. A gentle vortex was considered followed by incubation $\left(25^{\circ} \mathrm{C} / 15 \mathrm{~min}\right)$ in the darkroom. The tubes were provided with $400 \mu \mathrm{l}$ of $1 \mathrm{X}$ binding buffer. Flow cytometry was applied for analysis for $1 \mathrm{~h}$. The cells without any treatment were used as a control. Finally, the levels of apoptotic/necrotic cells were evaluated using flow cytometry.

\section{Gene expression analysis by real-time PCR RNA extraction}

Up to $1 \times 107$ cells were cultured in T25-flasks, and treated with different concentrations of M, and NM IC50 concentration for $72 \mathrm{~h}$. Add $1 \mathrm{ml}$ ice-cold RNX TM - PLUS solution to $2 \mathrm{ml}$ then tube containing homogenized sample. Vortex 5-10 s, and incubate at room temperature for $5 \mathrm{~min}$. Add $200 \mu \mathrm{l}$ of chloroform. Mix well for $15 \mathrm{~s}$ by shaking. Incubate on ice or $40{ }^{\circ} \mathrm{C}$ for $5 \mathrm{~min}$. Centrifuge at $12,000 \mathrm{rpm}$ at $40{ }^{\circ} \mathrm{C}$ for $15 \mathrm{~min}$. Transfer the aqueous phase to a new RNase-free 1.5-ml tube, (do not disturb the mid-phase), and add an equal volume of isopropanol. Gently mix, and incubate ice for $15 \mathrm{~min}$. Centrifuge the mixture at $12,000 \mathrm{rpm}$ at $40{ }^{\circ} \mathrm{C}$ for $15 \mathrm{~min}$. Discard the supernatant, and add $1 \mathrm{ml}$ of $75 \%$ Ethanol, shortly vortex to dislodge the pellet, and then centrifuge at $4{ }^{\circ} \mathrm{C}$ for $8 \mathrm{~min}$ at $7500 \mathrm{rpm}$. Discard the supernatant, and let the pellet dry at room temperature for a few minutes (do not let dry completely, it will decrease the solubility of the pellet. Dissolve pellet in $50 \mu \mathrm{l}$ of DEPC water. To dissolve, place the tube in a $55-60{ }^{\circ} \mathrm{C}$ water bath for $10 \mathrm{~min}$. Total RNA was extracted using Tripura reagent according to the manufacturer's instructions.

\section{CDNA synthesis}

Mix the template RNA (total RNA or Poly (A) mRNA) $1 \mathrm{ng}-5 \mu \mathrm{g}$, Buffer-Mix (2X) $10 \mu \mathrm{l}$, Enzyme-Mix $2 \mu \mathrm{l}$, and DEPC-treated water up to $20 \mu \mathrm{l}$ components in RNase-free tube. Mix the above mixture by quick vortex then incubate $10 \mathrm{~min}$ at $250^{\circ} \mathrm{C}$. Incubate $60 \mathrm{~min}$ at $470 \mathrm{C}$. Stop the reaction by heating at $850 \mathrm{C}$ for $5 \mathrm{~min}$. Chill on the ice or at $40{ }^{\circ} \mathrm{C}$. To perform PCR, you can add the finished RT reaction up to 1.5 of the final PCR volumes.

\section{Primer design, and real-time $P C R$}

The particular primers for Drp1, Mfn1, Bax, Bcl2, Caspase3, Caspase9, MMP2, MMP9, and $\beta$-actin (as internal control) were designed through the National Center for Biotechnology Information (NCBI) website (Table 6).

\section{Quantitative real-time $P C R$}

Experimental reaction by was performed by adding the components in this order, RealQ Plus, and 2X Master MIX (12.5 $\mu \mathrm{l} \mathrm{Vol./reaction,} \mathrm{1X),} \mathrm{Primer} \mathrm{A} 10 \mu \mathrm{M}(0.5 \mu \mathrm{l}(0.25-$ $2.5 \mu \mathrm{l})$ Vol./reaction, $0.1 \mu \mathrm{M}(0.05-0.5 \mu \mathrm{M}))$, Primer B $10 \mu \mathrm{M}(0.5 \mu \mathrm{l}(0.25-2.5 \mu \mathrm{l})$ Vol./ reaction, $0.1 \mu \mathrm{M}(0.05-0.5 \mu \mathrm{M})$, PCR-grade $\mathrm{H} 2 \mathrm{O}$ (10.5 $\mu \mathrm{l} \mathrm{Vol./reaction),} \mathrm{template} \mathrm{DNA}$ $(1 \mu \mathrm{l})$, and total volume is $25 \mu \mathrm{l}$, then gently mixed without creating bubbles. The reaction microtubes were placed in the instrument, and the appropriate program according 
to the manufacturer's instructions was run, $\left(1\right.$ Cycles, 15 min Duration of a cycle, $95{ }^{\circ} \mathrm{C}$ Temperature), and $\left(40\right.$ Cycles, $30 \mathrm{~s}$ duration of cycle in $95{ }^{\circ} \mathrm{C}$ Temperature, and $30 \mathrm{~s}$ duration of cycle in $61.5^{\circ} \mathrm{C}$ Temperature).

\section{In vivo study}

\section{Experimental animals, and ethical aspects}

All animal care and experimental procedures were carried out strictly following the criteria of the Institutional Animal Care, and Use Committee of Kharazmi University(Laboratories' Animal Center \& Cellular, and Molecular Research Laboratory, Kharazmi University, Tehran, Iran/ (ethical code: 16/11/2018-616/9745). All efforts were made to minimize the animals' suffering, and the numbers used. In this study 40 females, BALB/c inbred mice (weighing $18 \pm 2 \mathrm{~g}, 6$ to 8 weeks) were individually housed in polycarbonate animal cages, maintained under constant temperature $\left(22 \pm 2{ }^{\circ} \mathrm{C}\right)$, and humidity (55\%). The mice had free access to food, water, and were kept in $12 \mathrm{~h}$ light-dark cycles. After 1 week of acclimatization, the BALB/c mice were randomly divided into seven groups ( $n=5$ per group).

\section{Induction of breast cancer}

The experimental breast tumor was induced by subcutaneous injection of 4T1 tumor cells $(105 / \mathrm{mL}$ in suspension with phosphate-buffered saline, PBS 1X). The injection site was on the right side of the chest pad. 12th day after tumor induction, a solid tumor appeared subcutaneously. After 2 weeks, tumors were palpable. Tumor volume, and mice weight was measured by using a digital scale, and caliper so calculated according to Formula 1, and formula 2 mentioned below:

Formula $1:$ volume $=($ width 2$) \times$ length $/ 2$,

Formula 2: total volume $(\mathrm{mm} 3)=$ volume at last day $(\mathrm{mm}) /$ volume at first day $(\mathrm{mm}) \times 100$

\section{Study design}

Two doses of melittin-loaded niosome, and melittin were considered in treatment groups. Daily intraperitoneally (i.p.) injection of melittin for 20 days was performed. Healthy animals were divided into seven experimental groups of 5 mice each:

Gr.1-cancer control.

Gr.2-healthy control.

Gr 3-mice treated intraperitoneally (i.p.) with melittin at a dose of $3 \mathrm{mg} / \mathrm{kg}$.

Gr.4-mice treated intraperitoneally (i.p.) with melittin at a dose of $6 \mathrm{mg} / \mathrm{kg}$.

Gr.5-mice treated intraperitoneally (i.p.) with melittin-loaded niosome at a dose of $1.5 \mathrm{mg} / \mathrm{kg}$.

Gr.6-mice treated intraperitoneally (i.p.) with melittin-loaded niosome at a dose of $3 \mathrm{mg} / \mathrm{kg}$.

Gr.7-mice treated intraperitoneally (i.p.) with PBS.

Gr.8-mice treated intraperitoneally (i.p.) with Empty niosome at a dose of $6 \mathrm{mg} / \mathrm{kg}$. 


\section{Estimation of enzyme activity}

At the end of the study period, animal blood samples were taken then liver, and renal biomarkers were measured. The level of activity of aspartate aminotransferase (AST), alanine aminotransferase (ALT), alkaline phosphatase (ALP), albumin, creatinine, blood urea nitrogen (BUN), total protein in the collected samples was determined spectrometrically using "Pars Azmoon kit".

\section{Histopathology}

Histopathological evaluation and malignancy of breast cancer in the studied samples were performed using pleomorphism, mitosis, and invasion scoring:

$0=$ no pleomorphism $/ 1=$ small, regular nuclei, and a shape $/ 2=$ moderate degree of difference in size, shape of the nucleus, and hyperchromatic of the nucleus with the presence of nuclei $/ 3=$ severe degree of difference in nucleus size with hyperchromatic nuclei, and often with one or more nuclei identified. Subsequently, the mitosis index was evaluated in 10 fields with a magnification of 40 (HPF), the invasion index of the tumor cells was obtained, and the following divisions were obtained:

$0=$ no mitosis $/ 1=9-1$ mitosis $/ 2=10-19$ mitosis $/ 3=$ more than 20 mitosis.

$0=$ absence of tumor cells in dermis, and hypodermis $/ 1=$ penetration into dermis $/ 2=$ infiltration into hypodermis $/ 3=$ penetration into subcutaneous muscle tissue.

Daily intraperitoneally (i.p.) injection of samples for 20 days was performed. Three mice of each group were killed at the end of the treatment period. The tumor mass was removed, and fixed in $10 \%$ buffered formalin. Tumor tissues were processed in a tissue processor, and paraffin-embedded tissue sections were stained by the hematoxylin and eosin (H\&E) method. The tumor was histologically classified according to the Nottingham Histologic Score System (Meuten grade) (Meuten 2016). By this scoring system, the number of nuclear features, gland formation, and mitotic activity was assessed. All methods used in the study comply with the institutional ethical guidelines for care, and the use of animals in research.

\section{Immunohistochemical analysis of the tumors}

Tumor tissues were fixed in 10\% formalin buffer solution, washed three times in PBS, and left in 70\% ethanol. Tumors were kept in paraffin, and 5- $\mu \mathrm{m}$ sections were prepared. Hematoxylin, and Eosin staining, slides were dewaxed, hydrated using a decreasing solution bank of ethanol, stained with Gill's hematoxylin, dehydrated using 70\% ethanol, stained with eosin, further dehydrated using $100 \%$ ethanol, cleared using toluene, and mounted in coverslips using Acrymount IHC mounting media. Tumor cell apoptosis was determined in tissue sections by TUNEL assay (In Situ Cell Death Detection Kit, Roche).

\section{Statistical analysis}

Data were reported as mean $\pm \mathrm{SD}$, and the graphs were plotted using GraphPad Prism version 8. Data were statistically analyzed using analysis of variances (ANOVA) followed 
by a post-Tukey test, and a p-value less than 0.05 was considered as a significant difference.

\section{Abbreviations}

EE: Encapsulation efficiency; HLB: Hydrophilic-lipophilic balance; PDI: Polydispersity Index; SEM: Scanning electron microscopy; TEM: Transmission electron microscopy; DLS: Dynamic light scattering; HCC: Hepatocellular carcinoma cells; FITC: Annexin V fluorescein isothiocyanate; PI: Propidium iodide; PS: Phospholipid phosphatidylserine; FBS: Fetal bovine serum; PS: Penicillin/streptomycin; MTT: (Dimethylthiazol-2-yl-)-2, 5; DLS: Dynamic light scattering; H\&E: Hematoxylin and eosin; AST: Aspartate transaminase; ALT: Alanine aminotransferase; ALP: Alkaline phosphatase; BUN: Blood urea nitrogen.

\section{Acknowledgements}

Not applicable'for that section.

\section{Authors' contributions}

FDM, IA and PM developed the idea and designed the experiments. FDM, IA, EM, MF, LK, and MJ conducted the experiments. FDM and AR analyzed the data. FDM and AR wrote the manuscript. All authors confirmed the final manuscript before the submission. All authors read and approved the final manuscript.

Funding

This research did not receive any specific grant from funding agencies in the public, commercial, or not-for-profit sectors.

Availability of data and materials

All data were analyzed during this study are included in this published article.

\section{Declarations}

Ethics approval and consent to participate

There are no "human subjects" in this study.

\section{Consent for publication}

Not applicable.

\section{Competing interests}

The authors declare that they have no competing interests.

\section{Author details}

${ }^{1}$ Department of Biology, Science and Research Branch, Islamic Azad University, Tehran, Iran. ${ }^{2}$ Department of Chemical and Petrochemical Engineering, Sharif University of Technology, Tehran, Iran. ${ }^{3}$ Gastroenterology and Liver Diseases Research Center, Institute for Gastroenterology and Liver Diseases, Shahid Beheshti University of Medical Sciences, ResearchTehran, Iran. ${ }^{4}$ Department of Genetic, Tehran North Branch, Islamic Azad University, Tehran, Iran. ${ }^{5}$ Department of Chemical Engineering, Faculty of Engineering, Ferdowsi University of Mashhad, Mashhad, Iran. ${ }^{6}$ Department of Pathology, Faculty of Specialized Veterinary Science, Science and Research Branch, Islamic Azad University, Tehran, Iran.

Received: 23 February 2021 Accepted: 8 June 2021

Published online: 22 June 2021

\section{References}

Adade CM, Oliveira IR, Pais JA, Souto-Padrón T. Melittin peptide kills Trypanosoma cruzi parasites by inducing different cell death pathways. Toxicon. 2013;69:227-39.

Akbarzadeh I. Niosomal Formulation for Co-Administration of Hydrophobic Anticancer Drugs into MCF-7 Cancer Cells. Arch Adv Biosci. 2020;11:2

Akbarzadeh I, Yaraki MT, Bourbour M, Noorbazargan H, Lajevardi A, Shilsar SMS. Optimized doxycycline-loaded niosomal formulation for treatment of infection-associated prostate cancer: an in-vitro investigation. J Drug Del Sci Technol. 2020;57:101715

Akbarzadeh I, Shayan M, Bourbour M, Moghtaderi M, Noorbazargan H, Eshrati Yeganeh F. Preparation, Optimization and In-Vitro Evaluation of Curcumin-Loaded Niosome@ calcium alginate nanocarrier as a new approach for breast cancer treatment. Biology. 2021;10(3):173.

Alemi A, Reza JZ, Haghiralsadat F, Jaliani HZ, Karamallah MH, Hosseini SA. Paclitaxel and curcumin coadministration in novel cationic PEGylated niosomal formulations exhibit enhanced synergistic antitumor efficacy. J Nanobiotechnol. 2018;16(1):1-20.

Aleskandarany MA, Soria D, Green AR, Nolan C, Diez-Rodriguez M, Ellis IO. Markers of progression in early-stage invasive breast cancer: a predictive immunohistochemical panel algorithm for distant recurrence risk stratification. Breast Cancer Res Treat. 2015;151(2):325-33.

Amini E. Cytotoxic and pro-apoptotic effects of honey bee venom and chrysin on human ovarian cancer cells. Asia Pac J Med Toxicol. 2015;4(2):68-73.

Badria F, Fathy H, Fatehe A, Elimam D, Ghazy M. Evaluate the cytotoxic activity of honey, propolis, and bee venom from different localities in Egypt against liver, breast, and colorectal cancer. J Apither. 2017;2(1):1-4. 
Baillie A, Florence A, Hume L, Muirhead G, Rogerson A. The preparation and properties of niosomes-non-ionic surfactant vesicles. J Pharm Pharmacol. 1985;37(12):863-8.

Barrajón-Catalán E, Menéndez-Gutiérrez MP, Falco A, Carrato A, Saceda M, Micol V. Selective death of human breast cancer cells by lytic immunoliposomes: Correlation with their HER2 expression level. Cancer Lett. 2010;290(2):192-203.

Basu A, Haldar S. The relationship between Bcl2, Bax and p53: consequences for cell cycle progression and cell death. Mol Hum Reprod. 1998;4(12):1099-109.

Bazzo R, Tappin MJ, Pastore A, Harvey TS, Carver JA, Campbell ID. The structure of melittin. A 1H-NMR study in methanol. Eur J Biochem. 1988;173(1):139-46.

Bechinger B. Structure and functions of channel-forming peptides: magainins, cecropins, melittin and alamethicin. J Membr Biol. 1997;156(3):197-211.

Bello J, Bello HR, Granados E. Conformation and aggregation of melittin: dependence of pH and concentration. Biochemistry. 1982;21(3):461-5.

Benachir T, Lafleur M. Osmotic and pH transmembrane gradients control the lytic power of melittin. Biophys J . 1996;70(2):831-40.

Bouchalova K, Kharaishvili G, Bouchal J, Vrbkova J, Megova M, Hlobilkova A. Triple negative breast cancer-BCL2 in prognosis and prediction. Rev Curr Drug Targets. 2014;15(12):1166-75.

Callagy GM, Pharoah PD, Pinder SE, Hsu FD, Nielsen TO, Ragaz J. Bcl-2 is a prognostic marker in breast cancer independently of the Nottingham Prognostic Index. Clin Cancer Res. 2006;12(8):2468-75.

Cheng B, Thapa B, Remant K, Xu P. Dual secured nano-melittin for the safe and effective eradication of cancer cells. J Mater Chem B. 2015;3(1):25-9.

Choi EJ. Hesperetin induced G1-phase cell cycle arrest in human breast cancer MCF-7 cells: involvement of CDK4 and p21. Nutr Cancer. 2007;59(1):115-9.

Choi JE, Kang SH, Lee SJ, Bae YK. Prognostic significance of Bcl-2 expression in non-basal triple-negative breast cancer patients treated with anthracycline-based chemotherapy. Tumor Biol. 2014;35(12):12255-63.

Chou T-C. Drug combination studies and their synergy quantification using the Chou-Talalay method. Can Res. 2010;70(2):440-6.

Chu S-T, Cheng H-H, Huang C-J, Chang H-C, Chi C-C, Su H-H. Phospholipase A2-independent Ca2+ entry and subsequent apoptosis induced by melittin in human MG63 osteosarcoma cells. Life Sci. 2007;80(4):364-9.

Culp WD, Neal R, Massey R, Egevad L, Pisa P, Garland D. Proteomic analysis of tumor establishment and growth in the B16-F10 mouse melanoma model. J Proteome Res. 2006;5(6):1332-43.

DeGrado W, Musso G, Lieber M, Kaiser E, Kezdy F. Kinetics and mechanism of hemolysis induced by melittin and by a synthetic melittin analogue. Biophys J . 1982;37(1):329-38.

Deljoo S, Rabiee N, Rabiee M. Curcumin-hybrid nanoparticles in drug delivery system. Asian J Nanosci Mater. 2019;2(1):66-91.

Dempsey CH. The actions of melittin on membranes. Biochem Biophys Acta. 1990;1031(2):143-61.

Deng Y, Sriwiriyajan S, Tedasen A, Hiransai P. Graidist P (2016) Anti-cancer effects of Piper nigrum via inducing multiple molecular signaling in vivo and in vitro. J Ethnopharmacol. 2016;188:87-95.

Do N, Weindl G, Grohmann L, Salwiczek M, Koksch B, Korting HC. Cationic membrane-active peptides-anticancer and antifungal activity as well as penetration into human skin. Exp Dermatol. 2014;23(5):326-31.

Eisenberg D. Three-dimensional structure of membrane and surface proteins. Annu Rev Biochem. 1984;53(1):595-623.

Fan Q, Hu Y, Pang H, Sun J, Wang Z, Li J. Melittin protein inhibits the proliferation of MG63 cells by activating inositolrequiring protein-1 $\mathrm{a}$ and X-box binding protein 1-mediated apoptosis. Mol Med Rep. 2014;9(4):1365-70.

Fu Y, Kao WJ. Drug release kinetics and transport mechanisms of non-degradable and degradable polymeric delivery systems. Expert Opin Drug Deliv. 2010;7(4):429-44.

Fu J-Y, Tan DMY, Er HM, Chen YS, Nesaretnam K. Tumor-targeted niosome as novel carrier for intravenous administration of tocotrienol. Asian J Pharm Sci. 2016;11:79-80.

Ghafelehbashi R, Akbarzadeh I, Yaraki MT, Lajevardi A, Fatemizadeh M. Preparation, physicochemical properties, in vitro evaluation and release behavior of cephalexin-loaded niosomes. Int J Pharm. 2019;569:118580.

Hait WN, Grais L, Benz C, Cadman EC. Inhibition of growth of leukemic cells by inhibitors of calmodulin: phenothiazines and melittin. Cancer Chemother Pharmacol. 1985;14(3):202-5.

Hedayati Ch M, Abolhassani Targhi A, Shamsi F, Heidari F, Salehi Moghadam Z, Mirzaie A. Niosome-encapsulated tobramycin reduced antibiotic resistance and enhanced antibacterial activity against multidrug-resistant clinical strains of Pseudomonas aeruginosa. J Biomed Mater Res A. 2021;109(6):966-80.

Hematyar M, Soleimani M, Es-Haghi A, Rezaei Mokarram A. Synergistic co-delivery of doxorubicin and melittin using functionalized magnetic nanoparticles for cancer treatment: loading and in vitro release study by LC-MS/MS. Artif Cells Nanomed Biotechnol. 2018;46(sup3):S1226-35.

Hernandez-Aya LF, Gonzalez-Angulo AM. Adjuvant systemic therapies in breast cancer. Surg Clin North Am. 2013;93(2):473-91.

lochmann S, Bléchet C, Chabot V, Saulnier A, Amini A, Gaud G. Transient RNA silencing of tissue factor pathway inhibitor-2 modulates lung cancer cell invasion. Clin Exp Metas. 2009;26(5):457-67.

Ip S-W, Liao S-S, Lin S-Y, Lin J-P, Yang J-S, Lin M-L. The role of mitochondria in bee venom-induced apoptosis in human breast cancer MCF7 cells. Vivo. 2008;22(2):237-45.

Jallouk AP, Palekar RU, Marsh JN, Pan H, Pham CT, Schlesinger PH. Delivery of a protease-activated cytolytic peptide prodrug by perfluorocarbon nanoparticles. Bioconjug Chem. 2015;26(8):1640-50.

Jamasbi E, Mularski A, Separovic F. Model membrane and cell studies of antimicrobial activity of melittin analogues. Curr Top Med Chem. 2016;16(1):40-5.

Jang M-H, Shin M-C, Lim S, Han S-M, Park H-J, Shin I. Bee venom induces apoptosis and inhibits expression of cyclooxygenase-2 mRNA in human lung cancer cell line NCI-H1299. J Pharmacol Sci. 2003:91(2):95-104.

Jemal A, Bray F, Center MM, Ferlay J, Ward E, Forman D. Global cancer statistics. CA. 2011;61(2):69-90. 
Jo M, Park MH, Kollipara PS, An BJ, Song HS, Han SB. Anti-cancer effect of bee venom toxin and melittin in ovarian cancer cells through induction of death receptors and inhibition of JAK2/STAT3 pathway. Toxicol Appl Pharmacol. 2012;258(1):72-81.

Kanaani L. Effects of cisplatin-loaded niosomal nanoparticleson BT-20 human breast carcinoma cells. Asian Pac J Cancer Prev. 2017;18(2):365.

Kontoyannis A, Sweetland H. Adjuvant therapy for breast cancer. Surg Infect (larchmt). 2007;25(6):272-5.

Kubo H, Loegering DA, Adolphson CR, Gleich GJ. Cytotoxic properties of eosinophil granule major basic protein for tumor cells. Int Arch Allergy Immunol. 1999;118(2-4):426-8.

Kumar GP, Rajeshwarrao P. Nonionic surfactant vesicular systems for effective drug delivery—an overview. Acta Pharmaceutica Sinica B. 2011;1(4):208-19.

Ladokhin AS, Selsted ME, White SH. Sizing membrane pores in lipid vesicles by leakage of co-encapsulated markers: pore formation by melittin. Biophys J. 1997;72(4):1762-6.

Laprise-Pelletier M, Simão T, Fortin MA. Gold nanoparticles in radiotherapy and recent progress in nanobrachytherapy. Adv Healthcare Mater. 2018;7(16):1701460.

Lee M-T, Chen F-Y, Huang HW. Energetics of pore formation induced by membrane active peptides. Biochemistry. 2004:43(12):3590-9

Lee MT, Hung WC, Chen FY, Huang HW. Mechanism and kinetics of pore formation in membranes by water-soluble amphipathic peptides. Proc Natl Acad Sci. 2008;105(13):5087-92.

Li M, Tang Z, Zhang Y, Lv S, Li Q, Chen X. Targeted delivery of cisplatin by LHRH-peptide conjugated dextran nanoparticles suppresses breast cancer growth and metastasis. Acta Biomater. 2018;18:132-43.

Liu S, Yu M, He Y, Xiao L, Wang F, Song C. Melittin prevents liver cancer cell metastasis through inhibition of the Rac1dependent pathway. Hepatology. 2008;47(6):1964-73.

Mahale N, Thakkar P, Mali R, Walunj D, Chaudhari S. Niosomes: novel sustained release nonionic stable vesicular systems—an overview. Adv Coll Interface Sci. 2012;183:46-54.

Malekzadeh R, Derakhshan MH, Malekzadeh Z. Gastric Cancer in Iran. Epidemiol Risk Fact. 2009;12(6):576-83.

Mao J, Liu S, Ai M, Wang Z, Wang D, Li X. A novel melittin nano-liposome exerted excellent anti-hepatocellular carcinoma efficacy with better biological safety. J Hematol Oncol. 2017;10(1):71.

Meuten DJ. Diagnostic schemes and algorithms. Tum Domes Anim. 2002. https://doi.org/10.1002/9781119181200.

Misra SK, Ye M, Kim S, Pan D. Defined nanoscale chemistry influences delivery of peptido-toxins for cancer therapy. PLOS ONE. 2015;10(6):e0125908.

Moghaddam FD, Hamedi S, Dezfulian M. Anti-tumor effect of C-phycocyanin from Anabaena sp. ISC55 in inbred BALB/c mice injected with 4T1 breast cancer cell. Comp Clin Pathol. 2016;25(5):947-52.

Moghaddam FD, Mortazavi P, Hamedi S, Nabiuni M, Roodbari NH. Apoptotic effects of melittin on 4T1 breast cancer cell line is associated with up regulation of Mfn1 and Drp1 mRNA expression. Anti-Cancer Agents Med Chem. 2020;20(7):790-9.

Moon D-O, Park S-Y, Choi YH, Kim ND, Lee C, Kim G-Y. Melittin induces BCl-2 and caspase-3-dependent apoptosis through downregulation of Akt phosphorylation in human leukemic U937 cells. Toxicon. 2008;51(1):112-20.

Naderinezhad S, Amoabediny G, Haghiralsadat F. Co-delivery of hydrophilic and hydrophobic anticancer drugs using biocompatible pH-sensitive lipid-based nano-carriers for multidrug-resistant cancers. RSC Adv. 2017;7(48):30008-19.

Naji KM. Hepatoprotective activity of melittin on isoniazid and rifampicin induced liver damage in male albino rats. BioRxiv. 2020. https://doi.org/10.1101/2020.09.08.287094.

Nasseri B. Effect of cholesterol and temperature on the elastic properties of niosomal membranes. Int J Pharm. 2005;300(1-2):95-101.

Oršolić N. Bee venom in cancer therapy. Cancer Metastasis Rev. 2012;31(1-2):173-94.

Palit S, Kar S, Sharma G, Das PK. Hesperetin induces apoptosis in breast carcinoma by triggering accumulation of ROS and activation of ASK1/JNK pathway. J Cell Physiol. 2015;230(8):1729-39.

Pan H, Soman NR, Schlesinger PH, Lanza GM, Wickline SA. Cytolytic peptide nanoparticles ('NanoBees') for cancer therapy. Nanomed Nanobiotechnol. 2011;3(3):318-27.

Park JH, Jeong Y-J, Park K-K, Cho H-J, Chung I-K, Min K-S. Melittin suppresses PMA-induced tumor cell invasion by inhibiting NF-KB and AP-1-dependent MMP-9 expression. Mol Cells. 2010;29(2):209-15.

Park MH, Choi MS, Kwak DH, Oh KW, Yoon DY, Han SB. Anti-cancer effect of bee venom in prostate cancer cells through activation of caspase pathway via inactivation of NF-kB. Prostate. 2011;71 (8):801-12.

Pulaski BA, Ostrand-Rosenberg S. Mouse 4T1 breast tumor model. Curr Protoc Immunol. 2000;39(1):202.

Putri DA, Sutriyo S, Saputri FC. Cellular uptake study and cytotoxicity study of resveratrol-gold-peg-folate (RSVAUPEG-FA) nanoparticles on hela human cervical cancer cell line. Int J Appl Pharm. 2020;12(4):113-8.

Qiubo W. Study on the immune-regulating mechanism of the bee venom. Chin J Immunol. 2000;10:542-4.

Rady I, Siddiqui IA, Rady M, Mukhtar H. Melittin, a major peptide component of bee venom, and its conjugates in cancer therapy. Cancer Lett. 2017;402:16-31.

Reddy BS, Padman JSC, Santosh V. Niosomes as nanocarrier systems: a review. Int J Pharm Sci Res. 2012;3(6):1560.

Rinaldi F, Del Favero E, Rondelli V, Pieretti S, Bogni A, Ponti J. pH-sensitive niosomes: Effects on cytotoxicity and on inflammation and pain in murine models. J Enzyme Inhib Med Chem. 2017;32(1):538-46.

Ryu JS, Jang BH, Jo YS, Kim SJ, Eom TI, Kim MC. The effect of acteoside on intracellular Ca 2+ mobilization and phospholipase C activity in RBL-2H3 cells stimulated by melittin. Arch Pharmacal Res. 2014;37(2):239-44.

Saini SS, Chopra AK, Peterson JW. Melittin activates endogenous phospholipase D during cytolysis of human monocytic leukemia cells. Toxicon. 1999;37(11):1605-19.

Schweizer F. Cationic amphiphilic peptides with cancer-selective toxicity. Eur J Pharmacol. 2009;625(1-3):190-4.

Shad PM, Karizi SZ, Javan RS, Mirzaie A, Noorbazargan H, Akbarzadeh I. Folate conjugated hyaluronic acid coated alginate nanogels encapsulated oxaliplatin enhance antitumor and apoptosis efficacy on colorectal cancer cells (HT29 cell line). Toxicol in Vitro. 2020;65:104756. 
Sharon M, Oren Z, Shai Y, Anglister J. 2D-NMR and ATR-FTIR study of the structure of a cell-selective diastereomer of melittin and its orientation in phospholipids. Biochemistry. 1999;38(46):15305-16.

Shi W, Li C, Li M, Zong X, Han D, Chen Y. Antimicrobial peptide melittin against Xanthomonas oryzae pv oryzae, the bacterial leaf blight pathogen in rice. Appl Microbiol Biotechnol. 2016;100(11):5059-67.

Shin J-M, Jeong Y-J, Cho H-J, Park K-K, Chung I-K, Lee I-K. Melittin suppresses HIF-1 a/VEGF expression through inhibition of ERK and mTOR/p70S6K pathway in human cervical carcinoma cells. PLoS ONE. 2013;8(7):e69380.

Shirzad M, Jamehbozorgi S, Akbarzadeh I, Aghabozorg HR, et al. The role of polyethylene glycol size in chemical spectra, cytotoxicity, and release of PEGylated nanoliposomal cisplatin. Assay Drug Dev Technol. 2019;17(5):231-9.

Skalickova S, Heger Z, Krejcova L, Pekarik V, Bastl K, Janda J. Perspective of use of antiviral peptides against influenza virus. Viruses. 2015:7(10):5428-42.

Soman NR, Lanza GM, Heuser JM, Schlesinger PH, Wickline SA. Synthesis and characterization of stable fluorocarbon nanostructures as drug delivery vehicles for cytolytic peptides. Nano Lett. 2008;8(4):1131-6.

Soman NR, Baldwin SL, Hu G, Marsh JN, Lanza GM, Heuser JE. Molecularly targeted nanocarriers deliver the cytolytic peptide melittin specifically to tumor cells in mice, reducing tumor growth. J Clin Investig. 2009;119(9):2830-42.

Tosteson M, Tosteson D. Melittin forms channels in lipid bilayers. Biophys J. 1981;36(1):109-16.

van Sorge AA, Wijnen PH, van Delft JL, Coré-Bodelier VMC, van Haeringen NJ. Flurbiprofen, S (+), eyedrops: formulation, enantiomeric assay, shelflife and pharmacology. Pharm World Sci. 1999;21(2):91-5.

Vogel H, Jähnig F. The structure of melittin in membranes. Biophys J . 1986;50(4):573-82.

Wan L. TT-1, an analog of melittin, triggers apoptosis in human thyroid cancer TT cells via regulating caspase, $\mathrm{BCl}-2$ and Bax. Oncol Lett. 2018;15(1):1271-8.

Wang C, Chen T, Zhang N, Yang M, Li B, Lü X. Melittin, a major component of bee venom, sensitizes human hepatocellular carcinoma cells to tumor necrosis factor-related apoptosis-inducing ligand (TRAIL)-induced apoptosis by activating CaMKII-TAK1-JNK/p38 and inhibiting IkBa kinase-NFkB. J Biol Chem. 2009;284(6):3804-13.

Wang J, Li F, Tan J, Peng X, Sun L, Wang P. Melittin inhibits the invasion of MCF-7 cells by downregulating CD147 and MMP-9 expression. Oncol Lett. 2017;13(2):599-604.

Xu Y-Q, Chen W-R, Tsosie JK, Xie X, Li P, Wan J-B. Niosome encapsulation of curcumin: characterization and cytotoxic effect on ovarian cancer cells. J Nanomater. 2016. https://doi.org/10.1155/2016/6365295.

Yang L, Harroun TA, Weiss TM, Ding L, Huang HW. Barrel-stave model or toroidal model? A case study on melittin pores. Biophys J. 2001;81(3):1475-85.

Yu Y, Wang H, Yan A, Wang H, Li X, Liu J. Pretreatment neutrophil to lymphocyte ratio in determining the prognosis of head and neck cancer: a meta-analysis. BMC Cancer. 2018;18(1):383.

Zhang SF, Chen Z. Melittin exerts an antitumor effect on non-small cell lung cancer cells. Mol Med Rep. 2017;16(3):3581-6.

Zhang W, Wang F, Xu P, Miao C, Zeng X, Cui X. Perfluorooctanoic acid stimulates breast cancer cells invasion and upregulates matrix metalloproteinase-2/-9 expression mediated by activating NF-KB. Toxicol Lett. 2014;229(1):118-25.

Zhu X, Wang J, Wang R, Zhang X. Immunomodulatory effects of bee venom on S180 sarcoma mice. Pharmacol Clin Chin Materia Medica. 2000;16:24-5.

\section{Publisher's Note}

Springer Nature remains neutral with regard to jurisdictional claims in published maps and institutional affiliations.

Ready to submit your research? Choose BMC and benefit from:

- fast, convenient online submission

- thorough peer review by experienced researchers in your field

- rapid publication on acceptance

- support for research data, including large and complex data types

- gold Open Access which fosters wider collaboration and increased citations

- maximum visibility for your research: over $100 \mathrm{M}$ website views per year

At BMC, research is always in progress.

Learn more biomedcentral.com/submissions 